SILVA, Andrey Gastaldi. HEIL, Danielle Mariel. Paralelismo da legislação do modelo Common Law sobre a pena de morte e a redução da maioridade penal no ordenamento jurídico brasileiro. Revista Eletrônica Direito e Política, Programa de Pós-Graduação Stricto Sensu em Ciência Jurídic UNIVALI, Itajaí, v.11, n.3, $3^{\circ}$ quadrimestre de 2016. Disponível em: www.univali.br/direitoepc - ISSN 1980-7791

\title{
PARALELISMO DA LEGISLAÇÃO DO MODELO COMMON LAW SOBRE A PENA DE MORTE e A REDUÇÃo dA MAIORIDAdE PENAL NO ORDENAMENTO JURÍDICO BRASILEIRO
}

\author{
PARALLELISM OF COMMON LAW MODEL ON THE DEATH PENALTY AND THE \\ REDUCTION OF LEGAL AGE IN BRAZILIAN LEGAL SYSTEM
}

Andrey Gastaldi da Silva ${ }^{1}$

Danielle Mariel Heil ${ }^{2}$

SUMÁRIO: Introdução; 1. Direito penal norte-americano; 2. Texas: capital mundial das execuções; 3. Brasil e a pena de morte; 4 . Redução da maioridade penal no Brasil; Considerações finais; Referências das fontes citadas.

\section{RESUMO}

O trabalho proposto neste artigo científico tem por escopo realizar uma análise sobre as discussões acerca da pena de morte. A partir disso, tem-se como ponto de partida o Direito Penal nos Estados Unidos da América, o qual é adepto ao sistema common law, dando especial destaque ao Estado norte-americano do Texas, o qual é conhecido como capital mundial das execuções. Após, algumas considerações são feitas sobre a consagração da pena de morte no Brasil com a promulgação da Constituição da República Federativa de 1988, que, ainda de forma retencionista, estabelece a pena de morte em tempo de guerra. Analisa-se doutrina pertinente, com o objetivo de fazer um breve estudo sobre a previsão da pena de morte nos Estados Unidos e como o Brasil tem sustentado a adoção de tal pena. Por fim, apresentam-se as propostas de redução da maioridade penal que tramitam atualmente no Congresso Nacional brasileiro.

PALAVRAS-ChAVE: Pena de morte. Common law. Crime. Maioridade penal.

\footnotetext{
${ }^{1}$ Mestrando em Ciência Jurídica pela Universidade do Vale do Itajaí - UNIVALI. Graduado pela Universidade do Vale do Itajaí - UNIVALI. Advogado. andrey@edu.univali.br

2 Procuradora Adjunta do Município de Brusque-SC. Pós-graduada em Direito Penal e Processual Penal junto a Escola do Ministério Público do Estado de Santa Catarina. Pós-graduada em Direito Constitucional pela Fundação Educacional Damásio de Jesus. Pós-graduanda em Direito Ambiental pela instituição Verbo Jurídico. Mestranda em Ciências Jurídica pela Universidade do Vale do Itajaí - UNIVALI. dannyheil@hotmail.com
} 
SILVA, Andrey Gastaldi. HEIL, Danielle Mariel. Paralelismo da legislação do modelo Common Law sobre a pena de morte e a redução da maioridade penal no ordenamento jurídico brasileiro. Revista Eletrônica Direito e Política, Programa de Pós-Graduação Stricto Sensu em Ciência Jurídica da UNIVALI, Itajaí, v.11, n.3, $3^{\circ}$ quadrimestre de 2016. Disponível em: www.univali.br/direitoepolitica - ISSN 1980-7791

\section{ABSTRACT}

The work proposed in this research is to perform an analysis scope of the discussions about the death penalty. From this, has as its starting point the Criminal Law in the United States, which is adept at common law system, with particular attention to the U.S. state of Texas, which is known as the World Capital of Executions. After some considerations are made about the consecration of the death penalty in Brazil with the promulgation of the Federal Constitution of 1988, still retentionist way down the death penalty in time of war. We analyze relevant doctrine, in order to make a brief study on the prediction of the death penalty in the United States as Brazil has sustained the adoption of such penalty. Finally, we present the proposals to reduce the age of criminal currently proceed through the Brazilian National Congress.

KEYWORDS: Death penalty. Common law. Crime. Criminal responsibility.

\section{INTRODUÇÃO}

O presente estudo visa analisar acerca da legislação common law nos Estados Unidos da América, país da maior economia do globo e que adota a pena capital em alguns de seus Estados. A abordagem revela de forma breve acerca da legislação penal norte-americana, especialmente no Estado do Texas, o qual é utilizado como exemplo ao logo do estudo, por se tratar de um dos Estados norte-americanos mais rígidos na condenação de criminosos à pena de morte.

Com o passar do tempo, a pena foi humanizada, e a pena letal sofreu grandes críticas, principalmente após os ensinamentos de Beccaria, que pregava a humanização da pena. Assim, depois de ser duramente repudiada, a pena capital foi perdendo espaço para as penas menos severas, porém alguns países continuaram e até hoje continuam a usá-la como meio de controle social.

São apresentadas características, curiosidades e os pontos pelos quais alguns Estados aboliram a referida penalidade, porém diversos outros a mantém até os dias atuais.

Já com relação ao Brasil, este apesar de não aplicar a pena de morte há muito tempo, é considerado pela comunidade internacional como um país abolicionista 
SILVA, Andrey Gastaldi. HEIL, Danielle Mariel. Paralelismo da legislação do modelo Common Law sobre a pena de morte e a redução da maioridade penal no ordenamento jurídico brasileiro. Revista Eletrônica Direito e Política, Programa de Pós-Graduação Stricto Sensu em Ciência Jurídica da UNIVALI, Itajaí, v.11, n.3, $3^{\circ}$ quadrimestre de 2016. Disponível em: www.univali.br/direitoepolitica - ISSN 1980-7791

somente para delito comum, havendo essa reserva por conta da previsão constitucional da pena de morte em casos de guerra declarada, conforme contido no artigo $5^{\circ}$, inciso XLVII, alínea 'a' da Constituição da República Federativa do Brasil.

No mais, será demonstrado repúdio quanto à aprovação, em primeiro turno, na Câmara dos Deputados, no dia 02 de julho, de emenda aglutinativa à PEC no 171/93, apesar da rejeição da mesma matéria na votação do dia anterior, bem como se ressaltará acerca do incompleto grau de desenvolvimento em que se encontram os jovens adolescentes, tanto que por esta razão lhes foi dado tratamento especial por meio do Estatuto da Criança e do Adolescente.

\section{DIREITO PENAL NORTE-AMERICANO}

Para o desenvolvimento do presente artigo, é importante destacar a origem e características do modelo jurídico common law, bem como traçar breves diferenciações com relação à tradição do civil law, para posteriormente adentrar na temática do direito em si, a fim de propiciar uma melhor compreensão acerca do Direito Penal em solo norte-americano.

Tanto o Brasil como os Estados Unidos da América (EUA) têm sua justiça baseada em preceitos constitucionais, porém no Brasil vislumbra-se maior vinculação com a Constituição de 1988 , em razão de sua estrutura rígida ${ }^{3}$.

A nação norte-americana foi fundada a partir de três documentos básicos que compõem o sistema constitucional, conforme destaca Castro Júnior: "A Declaração da Independência, a Constituição Federal de 1787 e o Bill of Rights, sendo que para Castro Júnior o sucesso da Constituição norte-americana repousa na sua flexibilidade ${ }^{\prime 4}$.

\footnotetext{
${ }^{3}$ ALMEIDA, Sidney Silva de. O Supremo Tribunal Federal e os efeitos de suas decisões no controle difuso de constitucionalidade. Revista da Esmese, Aracaju, n.16, p.91-150, 2012.

4 CASTRO JÚNIOR, Osvaldo Agripino de. Introdução à história do Direito: Estados Unidos $x$ Brasil. Florianópolis: IBRADD/CESUSC, 2001, p. 60-63.
} 
SILVA, Andrey Gastaldi. HEIL, Danielle Mariel. Paralelismo da legislação do modelo Common Law sobre a pena de morte e a redução da maioridade penal no ordenamento jurídico brasileiro. Revista Eletrônica Direito e Política, Programa de Pós-Graduação Stricto Sensu em Ciência Jurídica da UNIVALI, Itajaí, v.11, n.3, $3^{\circ}$ quadrimestre de 2016. Disponível em: www.univali.br/direitoepolitica - ISSN 1980-7791

O Poder Judiciário americano, adepto do common law, possui uma Constituição enxuta, uma carta de princípios, e seu direito baseado em casos, onde cada decisão se torna jurisprudência por ser a expressão da moral da sociedade naquele momento ${ }^{5}$.

Sobre os países adeptos ao common law, preceitua Guido Fernandes Silva Soares:

A Common Law é um importante sistema de Direito que abriga mais de 54 países do globo, dentre os quais podemos citar: Austrália, Nova Zelândia, Quebec, Índia, Paquistão, Bangladesh, Quênia, Nigéria, Hong Kong, Guiana, Trinidad e Tobago, Barbados e Estados Unidos que em sua maioria (com exceção da Louisiana), pertence à família common law $w^{6}$.

No tocante às fontes do common law, pode se afirmar que o precedente judicial é sua fonte mais importante, pois é através dela que os juízes interpretam, em regra, a legislação?.

A Constituição Federal dos EUA, mesmo após mais de dois séculos de vigência, continua viva e atualizada, e já consagrava a supremacia do texto constitucional nos seguintes termos:

Esta Constituição, as leis dos Estados Unidos em sua execução e os tratados celebrados ou que houverem de ser celebrados em nome dos Estados Unidos constituirão o direito supremo do país. Os juízes de todos os Estados dever-Ihes-ão obediência, ainda que a Constituição ou as leis de algum Estado disponham em contrário ${ }^{8}$.

No tocante à diferenciação das tradições jurídicas advindas do common law e

${ }^{5}$ SOARES, Guido Fernandes Silva. Common Law: introdução ao Direito dos EUA. 2. ed. São Paulo: Revista dos Tribunais, 2000, p. 86.

${ }^{6}$ SOARES, Guido Fernandes Silva. Common Law: introdução ao Direito dos EUA. 2. ed. São Paulo: Revista dos Tribunais, 2000, p. 89.

7 CASTRO JÚNIOR, Osvaldo Agripino de. Introdução à história do Direito: Estados Unidos $\mathrm{x}$ Brasil. Florianópolis: IBRADD/CESUSC, 2001, p. 33.

8 CAMARGO, Marcelo Novelino. Leituras complementares de Direito Constitucional: controle de constitucionalidade. 2. ed. Salvador: JusPodivim, 2008, p. 284. 
SILVA, Andrey Gastaldi. HEIL, Danielle Mariel. Paralelismo da legislação do modelo Common Law sobre a pena de morte e a redução da maioridade penal no ordenamento jurídico brasileiro. Revista Eletrônica Direito e Política, Programa de Pós-Graduação Stricto Sensu em Ciência Jurídica da UNIVALI, Itajaí, v.11, n.3, $3^{\circ}$ quadrimestre de 2016. Disponível em: www.univali.br/direitoepolitica - ISSN 1980-7791

civil law, no que se refere ao direito penal, discorre Marco Bruno Miranda Clementino:

Enquanto na civil law se procurou criar um sistema racional,
prévio e abstrato, para a criminalização de condutas e
estabelecimento das respectivas sanções, na common law o
direito penal se expressa na proteção conferida pelo Estado
a liberdade do indivíduo. Assim, a dogmática penal se
estruturou por intermédio do processo penal, tendo como
referencial a defesa da liberdade individual ${ }^{9}$.

Para o direito penal norte-americano o "crime é a violação ou negligência de obrigação legal, de tal importância pública que o direito, costumeiro ou estatutário, toma conhecimento e implementa punição"10.

No tocante aos crimes no ordenamento jurídico estadunidense:

A maioria dos crimes é de competência estadual. São crimes federais os que dizem respeito à propriedade do governo central, ou que se dão em âmbito de diferentes estados, ou que evoquem problemas nacionais, como o combate ao narcotráfico, marco das administrações republicanas de Ronald Reagan e de George Bush ${ }^{11}$.

O direito criminal no sistema anglo-saxão é substancialmente um direito penal de feição inglesa, cuja herança afeta os modelos criminais estaduais. Em 1962 formatou-se um código penal modelo, o Model Penal Code (MPC), organizado pelo American Law Institute:

[...] Esse código foi desenvolvido por um grupo de juízes, advogados e professores de direito e é concebido para refletir o direito criminal nos Estados Unidos. O projeto começou em 1952. A justificativa para um código modelo prende-se na fragmentação dos direitos penais estaduais, frequentemente baseados em percepções de necessidades

${ }^{9}$ CLEMENTINO, Marco Bruno Miranda. A culpabilidade no Direito Internacional Penal. Revista CEJ, Brasília, Ano XIV, n. 51, p. 51-65, out./dez. 2010.

10 MAY, John Wilder. The Law of Crimes. Crime is a violation or neglect of legal duty, of so much public importance that the law, either common or statute, takes notice of and punishes it. Littleton: Fred B. Rothman, 1985, p. 1.

${ }^{11}$ BURNHAM, William. Introduction to the Law and Legal System of the United States. 3. ed. St. Paul, MN: West Group, 2002, p. 524. 
SILVA, Andrey Gastaldi. HEIL, Danielle Mariel. Paralelismo da legislação do modelo Common Law sobre a pena de morte e a redução da maioridade penal no ordenamento jurídico brasileiro. Revista Eletrônica Direito e Política, Programa de Pós-Graduação Stricto Sensu em Ciência Jurídica da UNIVALI, Itajaí, v.11, n.3, $3^{\circ}$ quadrimestre de 2016. Disponível em: www.univali.br/direitoepolitica - ISSN 1980-7791

públicas locais, sem demorados exames dessas situações específicas. O projeto estava basicamente completo em 1962, após a redação de treze ante-projetos. Desde 1962, aproximadamente dois terços dos estados têm adotado novos códigos penais, sob forte influência do código modelo ${ }^{12}$.

Segundo William Burnham, é a partir da divulgação desse código modelo que se fala em partes geral e especial, aquela indicando conceitos, essa identificando crimes em espécie, como na tradição da civil law do direito ocidental ${ }^{13}$.

O princípio da legalidade encontra-se constitucionalizado no artigo I, parágrafos 9 e 10 da Constituição dos EUA, na medida em que proíbem-se o bill of attainder e a ex post facto law (Constituição dos Estados Unidos da América, Artigo I, §§ 9 e 10).

No entendimento de Burnham:

O 'bill of attainter' consiste na legislação de exceção que declara específica pessoa culpada de crime e sujeita à penalidade, independentemente de julgamento ou condenação formal. A ex post facto law tipifica e penaliza comportamento pretérito, retroagindo em prejuízo do agente ${ }^{14}$.

Com relação ao distanciamento entre o modelo penal norte-americano, do common law, e o brasileiro da civil law, tem-se que:

Os Estados Unidos da América possuem um sistema diferenciado do Brasil. A Lei Penal é discutida e votada em cada estado que compõe o Estado maior, ou seja, cada estado possui lei penal própria para aplicação em seu território. É considerado um dos países com maior índice de execução em casos de pena de morte. Estados como o Mississipi, Texas, Flórida e Geórgia prevêem a aplicação da pena em seus limites aduaneiros. $O$ país que mais recentemente aboliu a

12 GODOY, Arnaldo Sampaio de Moraes. Direito penal nos Estados Unidos. Jus Navigandi, Teresina, ano 12, n. 1481, 22 jul. 2007. Disponível em: <http://jus.com.br/artigos/10179>. Acesso em: 10 mar. 2015.

13 BURNHAM, William. Introduction to the Law and Legal System of the United States. 3. ed. St. Paul, MN: West Group, 2002, p. 525.

14 BURNHAM, William. Introduction to the Law and Legal System of the United States. 3. ed. St. Paul, MN: West Group, 2002, p. 526. 
SILVA, Andrey Gastaldi. HEIL, Danielle Mariel. Paralelismo da legislação do modelo Common Law sobre a pena de morte e a redução da maioridade penal no ordenamento jurídico brasileiro. Revista Eletrônica Direito e Política, Programa de Pós-Graduação Stricto Sensu em Ciência Jurídica da UNIVALI, Itajaí, v.11, n.3, $3^{\circ}$ quadrimestre de 2016. Disponível em: www.univali.br/direitoepolitica - ISSN 1980-7791

aplicação da pena de morte foi o Uzbequistão, no início do ano passado ${ }^{15}$.

Para Barry Latzer, no sistema norte-americano adepto ao common law, diferentemente do sistema jurídico brasileiro, os denominados Juveniles, ou seja, adolescentes, à época do crime podem ser executados ${ }^{16}$.

Na concepção de Harvey Wallace e Cliff Roberson acerca da determinação de imputabilidade penal:

A imputabilidade penal é muito flexível nos Estados Unidos, sendo que os menores de sete anos são inimputáveis, já entre sete e quatorze anos há presunção de que a criança ainda não adquiriu perfeita capacidade mental. Entre quatorze e dezessete anos há justiça especializada para determinar a culpabilidade (juvenile courts) ${ }^{17}$.

Já no tocante ao processo criminal, Arnaldo Sampaio de Moraes Godoy ensina que:

Este divide-se em duas partes distintas de acordo com a pena aplicável: as ofensas graves (felonies), puníveis com penas severas, inclusive a pena de morte, e a misdemeanour, que são ofensas penais menos graves, puníveis em reformatórios e nas cadeias públicas ${ }^{18}$.

Portanto, observa-se que o instituto da pena de morte é utilizado como sanção para as penas ditas como severas em solo estadunidense.

Na visão de Gilberto Callado de Oliveira, alguns Estados utilizam a própria eternidade em sua justiça penal, como a prisão perpétua e a pena capital, no

${ }^{15}$ OLIVEIRA, Gleick Meira; LIMA, Rebecca Rocha. Do Direito Penal brasileiro: das penas e da pena de morte. Postado em: 2011. Disponível em:<http://www.ambito-juridico.com.br/site/ index.php?n_link=revista_artigos_leitura\&artigo_id=9101>. In: Âmbito Jurídico, Rio Grande, XIV, n. 86, mar 2011. Acesso em: 15 mar. 2015.

${ }^{16}$ LATZeR, Barry. Death Penalty Cases. New York: Butterworth Heinemann, 2002, p. 235.

17 WALLACE, Harvey; ROBERSON, Cliff. Principles of Criminal Law. White Plains: Longman, 1996, p. 74.

18 GODOY, Arnaldo Sampaio de Moraes. Direito penal nos Estados Unidos. Jus Navigandi, Teresina, ano 12, n. 1481, 22 jul. 2007. Disponível em: <http://jus.com.br/artigos/10179>. Acesso em: 10 mar. 2015. 
SILVA, Andrey Gastaldi. HEIL, Danielle Mariel. Paralelismo da legislação do modelo Common Law sobre a pena de morte e a redução da maioridade penal no ordenamento jurídico brasileiro. Revista Eletrônica Direito e Política, Programa de Pós-Graduação Stricto Sensu em Ciência Jurídica da UNIVALI, Itajaí, v.11, n.3, $3^{\circ}$ quadrimestre de 2016. Disponível em: www.univali.br/direitoepolitica - ISSN 1980-7791

sentido de indicar que neles existem crimes irremissíveis ${ }^{19}$.

Nos EUA, segundo Serrano, a maioria dos Estados que adota a pena de morte, a decisão da vida ou da morte do criminoso cabe ao júri popular, sem intervenção do juiz ou de autoridades que possam absolver o criminoso. A vontade do povo, democraticamente demonstrada através das pessoas do povo, em sua decisão no júri, é soberana 20 .

Cumpre registrar que em 1972 a Suprema Corte baniu a pena de morte, sob premissa de crueldade, decisão revertida em 1976 quando os estados reformularam suas leis de execução.

Como é de se saber, os EUA possuem diversos poderes e relativa autonomia em relação ao governo federal, o que os torna relativamente independentes ao governo federal e permite certa autonomia para que os 50 estados que compõem este país possam regular a sua própria justiça ${ }^{21}$.

Isso explica o fato de que em alguns estados dos EUA admite-se, por exemplo, a pena de morte e a prisão perpétua e em outros não.

Dentre os estados norte-americanos mais desrespeitadores dos direitos das populações prisionais na América está o Texas, sendo aquele que aplica mais penas de morte ${ }^{22}$, conforme se demonstrará a seguir.

19 OLIVEIRA, Gilberto Callado de. Garantismo e barbárie: a face oculta do garantismo penal. São Paulo: Conceito Editorial, 2011, p. 55.

20 SERRANO, Rodrigo Fagundes Luz. Pena de morte: aspectos jurídicos e religiosos. Postado em: 2008. Disponível em:<http://pt.scribd.com/doc/68141078/ARTIGO>. Acesso em: 16 maio 2015.

21 PAZZIAN, Roberta Mucare. A descaracterização da prisão como forma de ressocializar o indivíduo, p. 01. Postado em: 2012. Disponível em: <http://www.conamp.org.br/Lists/artigos/ DispForm.aspx?ID=220\&Source=/>. Acesso em: 12 abr. 2015.

22 PAZZIAN, Roberta Mucare. A descaracterização da prisão como forma de ressocializar o indivíduo, $\quad$ p. 01 Postado em: 2012. Disponível em: <http://www.conamp.org.br/Lists/artigos/Disp Form.aspx?ID=220\&Source=/>. Acesso em: 12 abr. 2015. 
SILVA, Andrey Gastaldi. HEIL, Danielle Mariel. Paralelismo da legislação do modelo Common Law sobre a pena de morte e a redução da maioridade penal no ordenamento jurídico brasileiro. Revista Eletrônica Direito e Política, Programa de Pós-Graduação Stricto Sensu em Ciência Jurídica da UNIVALI, Itajaí, v.11, n.3, $3^{\circ}$ quadrimestre de 2016. Disponível em: www.univali.br/direitoepolitica - ISSN 1980-7791

\section{TEXAS: CAPITAL MUNDIAL DAS EXECUÇÕES}

Destacados os pontos acerca da legislação penal que engloba todo o território norte-americano, a partir de agora será dado especial enfoque a questão da adoção da penal capital no Estado do Texas.

Vale destacar que o Estado do Texas possui um papel muito importante no que tange à pena de morte, devido à grande quantidade de execuções. Por esta razão ele possui o título de 'Huntsville: Capital Mundial das Execuções'²3.

Quando a pena de morte foi declarada pela Suprema Corte dos Estados Unidos, em 29 de junho de 1972, como cruel e irregular havia 45 homens no corredor da morte no Texas, e 07 homens presos nos municípios com sentenças de morte a serem cumpridas. Todas as sentenças foram convertidas em liberdade pelo Governador do Texas, e em março de 1973, o corredor da morte estava vazio ${ }^{24}$.

Ainda no mesmo ano, preceitua Ana Paula Krentz Xavier:

Uma alteração no Código Penal do estado permitiu novamente a aplicação da pena capital, e foram retomadas as execuções em 01 de janeiro de 1974, sendo que o primeiro homem a ser mandado ao corredor da morte foi John Devries, em 15 de fevereiro de 1974. Ele acabou cometendo suicídio por enforcamento em 01 de julho do mesmo ano, utilizando os lençóis de sua cama ${ }^{25}$.

Desde que a pena de morte foi restabelecida em 1976, o Estado do Texas liderou o número de execuções, sendo que junto com a Califórnia, Flórida e Pensilvânia,

23 TEXAS DEPARTAMENT OF CRIMINAL JUSTICE. Death Row Facts: history, p. 01. Postado em: 2014. Disponível em: <https://www.tdcj.state.tx.us/death_row/dr_facts.html>. Acesso em: 21 abr. 2015.

24 TEXAS DEPARTAMENT OF CRIMINAL JUSTICE. Death Row Facts: history, p. 01. Postado em: 2014. Disponível em: <https://www.tdcj.state.tx.us/death_row/dr_facts.html>. Acesso em: 21 abr. 2015.

${ }^{25}$ XAVIER, Ana Paula Krentz. Aplicabilidade e eficácia da pena de morte como instrumento de defesa social: estudo de caso nos Estados Unidos da América. 2004. 99 f. Monografia (Bacharel em Direito) - Universidade do Vale do Itajaí, São José, 2004, p. 66. Disponível em: <http://siaibib01. univali.br/pdf/Ana\%20Xavier.pdf>. Acesso em: 14 mar. 2015. 
SILVA, Andrey Gastaldi. HEIL, Danielle Mariel. Paralelismo da legislação do modelo Common Law sobre a pena de morte e a redução da maioridade penal no ordenamento jurídico brasileiro. Revista Eletrônica Direito e Política, Programa de Pós-Graduação Stricto Sensu em Ciência Jurídica da UNIVALI, Itajaí, v.11, n.3, $3^{\circ}$ quadrimestre de 2016. Disponível em: www.univali.br/direitoepolitica - ISSN 1980-7791

possuem as maiores populações do corredor da morte ${ }^{26}$.

Acerca da execução dos condenados, vale registrar:

Em janeiro de 1996, foi permitido aos parentes próximos e amigos da vítima observarem as execuções, sendo que o método mais utilizado no estado atualmente é a injeção letal, que foi adotada em 1977, e é composta de sódio tiopental (um barbitúrico), que primeiro anestesia o indivíduo, de brometo, que relaxa seus músculos, e por fim, de cloreto de potássio, que para as batidas do coração. A morte do executado é geralmente pronunciada 07 (sete) minutos depois da injeção letal começar a agir ${ }^{27}$.

No ano de 2002, 71 prisioneiros foram executados, 33 deles apenas no Texas, que liderou o número de execuções por estado. Destes, 69 eram homens e 02 eram mulheres, no total de 53 brancos, 18 negros e entre todos, 06 latinos, sendo que a idade média dos condenados é de 28 anos $^{28}$.

Ademais, de acordo com o Código Penal do Estado do Texas, se o juiz ou júri, quando autorizados por lei, não tiver absoluta certeza que o acusado é culpado dos crimes descritos, ele pode condená-lo a uma pena inferior ${ }^{29}$.

Portanto, segundo as normas da capital mundial das execuções, é possível evidenciar que não há aplicação do in dubio pro reo, diferentemente da legislação penal brasileira, no qual este princípio vigora como verdadeiro divisor de águas.

Portanto, no Estado norte-americano do Texas:

26 TEXAS DEPARTAMENT OF CRIMINAL JUSTICE. Death Row Facts: history, p. 01. Postado em: 2014. Disponível em: <https://www.tdcj.state.tx.us/death_row/dr_facts.html>. Acesso em: 21 abr. 2015.

27 XAVIER, Ana Paula Krentz. Aplicabilidade e eficácia da pena de morte como instrumento de defesa social: estudo de caso nos Estados Unidos da América. 2004. 99 f. Monografia (Bacharel em Direito) - Universidade do Vale do Itajaí, São José, 2004, p. 66. Disponível em: <http://siaibib01. univali.br/pdf/Ana\%20Xavier.pdf>. Acesso em: 14 mar. 2015.

${ }^{28}$ ESTADOS UNIDOS DA AMÉRICA. Bureau of Justice Statistics: Capital Punishment. Disponível em: <http://www.ojp.usdoj.gov>. Acesso em: 21 abr. 2015.

29 TeXAS legislature OnLine. Texas Statutes. Penal Code, p. 01. Disponível em: <http://www. capitol state.tx.us>. Acesso em: 21 abr. 2015. 
SILVA, Andrey Gastaldi. HEIL, Danielle Mariel. Paralelismo da legislação do modelo Common Law sobre a pena de morte e a redução da maioridade penal no ordenamento jurídico brasileiro. Revista Eletrônica Direito e Política, Programa de Pós-Graduação Stricto Sensu em Ciência Jurídica da UNIVALI, Itajaí, v.11, n.3, $3^{\circ}$ quadrimestre de 2016. Disponível em: www.univali.br/direitoepolitica - ISSN 1980-7791

Juiz é quem prolata a sentença de morte, sendo que o Governador possui autoridade sobre o conselho da comissão de absolvição e liberdade condicional. Ele necessita de uma recomendação favorável da comissão para que possa conceder o perdão ao sentenciado à morte, porém não é obrigado a seguir essa recomendação ${ }^{30}$.

Nesse sentido, enfatiza Maria Ignês de Souza Bierrenbach:

A pena capital não é nada mais do que a institucionalização pelo Estado de um dos mecanismos criados pela população na tentativa de combater o acirramento da violência, enquanto grupos de extermínio, justiceiros e outros criminosos são instrumentos informais e oficiosos ${ }^{31}$.

Acerca do estudo de alguns doutrinadores a respeito da pena de morte, dá-se especial atenção a Beccaria, devido às suas marcantes inovações à frente das Escolas Penais.

Deste modo, oportuno se faz ressaltar o entendimento de Cesare Beccaria, o qual condena a crueldade das sanções que eram impostas em sua época, sustentando que:

Uma pena para ser justa, precisa apenas ter o grau de rigor suficiente para afastar os homens da senda do crime. Ora, não existe homem que hesite entre o crime, apesar das vantagens que este enseje, e o risco de perder para sempre a liberdade $[\ldots]^{32}$.

Nessa mesma linha de raciocínio:

Alguns países, como é o caso do Japão, China e Estados Unidos da América utilizam a pena de morte como punição para crimes bárbaros. Existe uma controvérsia em relação a sua funcionalidade, já que nesses países, em especial nos Estados Unidos da América, que utilizam a pena, a criminalidade só tende a crescer, através de um

\footnotetext{
${ }^{30}$ TEXAS Legislature ONLINE. Texas Statutes. Penal Code, p. 01. Disponível em: <http://www. capitol state.tx.us>. Acesso em: 21 abr. 2015.

31 BIERRENBACH, Maria Ignês de Souza. A favor da vida: contra a pena de morte. São Paulo: Cortez, 1993, p. 34.

32 BECCARIA, Cesare. Dos delitos e das penas. São Paulo: Martin Claret, 2001, p. 54.
} 
SILVA, Andrey Gastaldi. HEIL, Danielle Mariel. Paralelismo da legislação do modelo Common Law sobre a pena de morte e a redução da maioridade penal no ordenamento jurídico brasileiro. Revista Eletrônica Direito e Política, Programa de Pós-Graduação Stricto Sensu em Ciência Jurídica da UNIVALI, Itajaí, v.11, n.3, $3^{\circ}$ quadrimestre de 2016. Disponível em: www.univali.br/direitoepolitica - ISSN 1980-7791

levantamento feito pela Confederação Européia dos Direitos Humanos ${ }^{33}$.

Sobre essa questão da funcionalidade da pena de morte, a seguir serão apresentadas uma série de características acerca do instituto da pena de morte, bem como evidências que demonstram como o sistema penal norte-americano adepto a penal capital é falho, ressaltando-se, que atualmente, 31 dos 50 estados norte-americanos aderem a penal capital. Jurisdições sem estatutos de pena de morte são: Alaska, Connecticut, Distrito de Columbia, Havaí, Illinois, Iowa, Maine, Maryland, Massachusetts, Michigan, Minnesota, New Jersey, New Mexico, New York, North Dakota, Rhode Island, Vermont, Virgínia Ocidental, e Wisconsin ${ }^{34}$.

Acerca desta questão, pontua Amaral:

Estudos demonstram que dos 36 estados americanos que adotam a pena de morte, o índice de assassinatos por 100 mil habitantes é muito maior do que nos outros 14 estados que não condenam a morte. O que demonstra a ineficácia da pena consubstanciada no desrespeito ao ser humano e vulgarização da vida ${ }^{35}$.

Nas palavras de Bierrenbach:

Pesquisa do ONU demonstra: na Inglaterra, onde não existe pena de morte, ocorre um homicídio para cada cem mil habitantes/ano. Nos Estados Unidos, onde há pena de morte, são dez homicídios para cada cem mil habitantes. Nos estados da Califórnia, Texas e Flórida, onde há pena de morte, o número de homicídios é significativamente maior do que nos estados de Dakota do Norte ou Vermont, onde ela não existe (no ano de 1991, respectivamente, 3550,

33 OLIVEIRA, Gleick Meira; LIMA, Rebecca Rocha. Do Direito Penal brasileiro: das penas e da pena de morte. Postado em: 2011. Disponível em: <http://www.ambitojuridico.com.br/site/ index.phpn_link=revista_artigos_leitura\%26artigo_id=9101"artigo_id=9101>. Acesso em: 15 mar. 2015.

34 TEXAS DEPARTAMENT OF CRIMINAL JUSTICE. Death Row Facts: history, p.01. Postado em: 2014. Disponível em: <https:// www.tdcj.state.tx.us/death_row/dr_facts.html>. Acesso em: 21 abr. 2015.

35 AMARAL, Carneiro Ariel. Pena de morte. JusBrasil, 2013. Disponível em: <http://carneiro.jus brasil.com.br/artigos/111686526/pena-de-morte>. Acesso em: 12 mar. 2015. 
SILVA, Andrey Gastaldi. HEIL, Danielle Mariel. Paralelismo da legislação do modelo Common Law sobre a pena de morte e a redução da maioridade penal no ordenamento jurídico brasileiro. Revista Eletrônica Direito e Política, Programa de Pós-Graduação Stricto Sensu em Ciência Jurídica da UNIVALI, Itajaí, v.11, n.3, $3^{\circ}$ quadrimestre de 2016. Disponível em: www.univali.br/direitoepolitica - ISSN 1980-7791

$$
\text { 2690, } 1140 \text { contra } 8 \text { e } 22 \text { homicídios) }{ }^{36} \text {. }
$$

Já Bittencourt, destaca acerca da ineficácia da pena de morte em reprimir os impulsos criminosos:

Em nenhum dos países que adotaram a pena capital no passado ou adotam ainda no presente, atuou ela como fator de inibição da criminalidade. O exemplo clássico desse caso é o dos Estados Unidos. Lá, apesar do espectro ameaçador da câmara de gás, da cadeira elétrica e, mais recentemente, da injeção letal, os índices de criminalidade nunca diminuíram por causa do temor supostamente inspirado pela pena de morte. Tanto assim é que vem diminuindo o número de estados que ainda insistem em mantê-la e, mesmo nestes, o número de execuções é cada vez menor. É fato cada vez mais evidente para os especialistas que o criminoso não se intimida com a severidade das penas ${ }^{37}$.

Assim, na visão de Sousa:

A pena de morte não possui nenhuma comprovação científica de exercer influência efetiva na prevenção da delinquência. Ao contrário, no estado do Texas (EUA), por exemplo, verificou-se após a adoção da medida punitiva, visível incremento nos índices de criminalidade, ao passo que na França, onde a referida medida encontra-se sem vigência, a quantidade de homicídios não sofreu impacto ${ }^{38}$.

Sobre a quantidade de execuções ocorridas em solo norte-americano, ressalva referido autor:

Entre os anos de 1608 a 1985, aconteceram quatro mil execuções nos Estados Unidos; proporcionalmente à população, a violência americana é dez vezes maior que a brasileira, não obstante a pena de morte. Não há notícia de aumento da criminalidade nos países que aboliram a

36 BIERRENBACH, Maria Ignês de Souza. A favor da vida: contra a pena de morte. São Paulo: Cortez, 1993, p. 34.

37 BITTENCOURT, Daniela Almeida. Previsão Constitucional da pena de morte no Brasil e suas implicações no atual contexto global em prol dos Direitos Humanos. Postado em: 2012. Disponível em: <http://www.publicadireito.com.br/artigos/?cod=1e747ddbea997a1b>. Acesso em: 24 abr. 2015.

38 SOUSA, Carlos Arruda. O debate da pena de morte: seus defensores e opositores. Âmbito Jurídico, Rio Grande, X, n. 38, fev. 2007. Disponível em: <http://www.ambito-juridico.com. br/site/ index.php?n_link=revista_artigos_leitura\&artigo_id=3430>. Acesso em: 21 abr. 2015. 
SILVA, Andrey Gastaldi. HEIL, Danielle Mariel. Paralelismo da legislação do modelo Common Law sobre a pena de morte e a redução da maioridade penal no ordenamento jurídico brasileiro. Revista Eletrônica Direito e Política, Programa de Pós-Graduação Stricto Sensu em Ciência Jurídica da UNIVALI, Itajaí, v.11, n.3, $3^{\circ}$ quadrimestre de 2016. Disponível em: www.univali.br/direitoepolitica - ISSN 1980-7791

medida, tampouco anseio social solicitando seu retorno, o que corrobora a inverdade do poder de intimidação da pena ${ }^{39}$.

Sousa descreve minuciosamente sobre o caráter inócuo da adoção da pena capital:

A aplicação da pena capital não é capaz de produzir queda dos índices de criminalidade, ainda que se possa contraargumentar favoravelmente, alegando que as penas restritivas de liberdade também não logram fazê-lo; o caráter inócuo da medida no tocante à profilaxia social é flagrante. Determinados criminosos apenas obedecem a seus impulsos, simplesmente não deixarão de agir, sendo irrelevante a sanção cominada, ainda que severa, seja reclusão prolongada ou mesmo a extinção da vida. Alguns agem em virtude da atração que o risco exerce, servindo de modo contrário, a pena, como um estimulante ao delito ${ }^{40}$.

É conveniente ressaltar sobre as pessoas erroneamente condenadas à morte no sistema anglo-saxão:

Os Estados Unidos são o país que mais pessoas executa em todo o mundo ocidental. Em 1972 um estudo revelou que pelo menos 350 pessoas foram erradamente condenadas à morte neste país durante o século $X X$, não apenas por erro, mas também em consequência de conspirações policiais, de procuradores, juristas, testemunhas, advogados de defesa e até de jurados, sendo que dentre os estados que decretam mais condenações estão os estados da Califórnia, Texas e Florida $^{41}$.

Segundo Jean Frederick Silva e Souza, a Anistia Internacional, mesmo os EUA, país que se orgulha e é referência para o mundo por ter um sistema legal equilibrado e justo, foram compelidos a soltar, desde 1975, mais de oitenta e

39 SOUSA, Carlos Arruda. O debate da pena de morte: seus defensores e opositores. Âmbito Jurídico, Rio Grande, X, n. 38, fev. 2007. Disponível em: <http://www.ambito-juridico.com. br/site/ index.php?n_link=revista_artigos_leitura\&artigo_id=3430>. Acesso em: 21 abr. 2015.

40 SOUSA, Carlos Arruda. O debate da pena de morte: seus defensores e opositores. Âmbito Jurídico, Rio Grande, X, n. 38, fev. 2007. Disponível em: <http://www.ambito-juridico.com. br/site/ index.php?n_link=revista_artigos_leitura\&artigo_id=3430>. Acesso em: 21 abr. 2015.

41 PAZZIAN, Roberta Mucare. A descaracterização da prisão como forma de ressocializar o indivíduo. Postado em: 2012. Disponível em: <http://www.conamp.org.br/Lists/artigos/Disp Form.aspx?ID=220\&Source=/>. Acesso em: 12 abr. 2015. 
SILVA, Andrey Gastaldi. HEIL, Danielle Mariel. Paralelismo da legislação do modelo Common Law sobre a pena de morte e a redução da maioridade penal no ordenamento jurídico brasileiro. Revista Eletrônica Direito e Política, Programa de Pós-Graduação Stricto Sensu em Ciência Jurídica da UNIVALI, Itajaí, v.11, n.3, $3^{\circ}$ quadrimestre de 2016. Disponível em: www.univali.br/direitoepolitica - ISSN 1980-7791

cinco apenados, condenados à pena de morte, em virtude de se provar, posteriormente, que eram inocentes. Quanto ao seu poder intimidativo, ficou comprovado, pelas estatísticas realizadas nos países que a mantêm, que, na maioria dos casos, ocorreu o aumento da criminalidade, enquanto que em pouquíssimos houve um decréscimo ${ }^{42}$.

Conforme se vislumbra do Relatório Mundial dos Estados Unidos da América, este país a maior população encarcerada contabilizada no mundo e, de longe, a taxa de encarceramento mais elevada. No final de 2011, 2,2 milhões de pessoas estavam presas em prisões ou cadeias para adultos ${ }^{43}$.

Para fazer um paralelo com a população carcerária brasileira, os números apresentados pelo Conselho Nacional de Justiça, no mês de junho do corrente ano, observa-se que o país possui 715.655 presos.

Com as novas estatísticas, o Brasil passa a ter a terceira maior população carcerária do mundo, segundo dados do ICPS, sigla em inglês para Centro Internacional de Estudos Prisionais, do King's College, de Londres. As prisões domiciliares fizeram o Brasil ultrapassar a Rússia, que tem 676.400 presos $^{44}$.

A revista científica Proceedings of the National Academy of Sciences estima que pelo menos $4,1 \%$ dos condenados à morte nos EUA são inocentes ${ }^{45}$ - uma em

42 SOUZA, Jean Frederick Silva e. Pena de Morte: solução da violência ou violação do direito à vida? Revista de Direito e Liberdade, Escola da Magistratura do RN, Mossoró, v. 07, n. 03, p. 161178, jul./dez. 2007.

43 RELATÓRIO MUNDIAL DOS ESTADOS UNIDOS DA AMÉRICA. Resumo do País. Human Rights Watch, p. 01-13, jan. 2014. Disponível em: <http://www.hrw.org/sites/default/files/rela ted_material/ US_pt\%202014\%2001\%2004.pdf>. Acesso em: 02 maio 2015.

44 MONTENEGRO, Manuel. CNJ divulga dados sobre nova população carcerária brasileira. Atualizado: 12 jun. 2014. Disponível em: <http://www.cnj.jus.br/noticias/cnj/28746-cnj-divulgadados-sobre-nova-populacao-carceraria-brasileira>. Acesso em: 08 jun. 2015.

45 "Para o diretor-executivo do Death Penalty Information Center (Centro de Informações sobre a Pena de Morte), Richard Dieter, o estudo confirma o principal temor em relação à pena de morte: o de que inocentes estejam sendo punidos por crimes que não cometeram" (GOMES, Nelci. Mais de $4 \%$ dos condenados à morte nos EUA são inocentes, indica estudo. JusBrasil, maio $2014, p$. 01. Disponível em: <http://nelcisgomes.jusbrasil.com.br/noticias/117938 062/mais-de-4-doscondenados-a-morte-nos-eua-sao-inocentes-indica-estudo?ref=home>. Acesso em: 27 maio 2015). 
SILVA, Andrey Gastaldi. HEIL, Danielle Mariel. Paralelismo da legislação do modelo Common Law sobre a pena de morte e a redução da maioridade penal no ordenamento jurídico brasileiro. Revista Eletrônica Direito e Política, Programa de Pós-Graduação Stricto Sensu em Ciência Jurídica da UNIVALI, Itajaí, v.11, n.3, $3^{\circ}$ quadrimestre de 2016. Disponível em: www.univali.br/direitoepolitica - ISSN 1980-7791

cada 25 pessoas condenadas ${ }^{46}$.

No entanto, não obstante a cota de encarceramento dos Estados Unidos ser a mais elevada do mundo, isso não produz qualquer efeito significativo na redução da delinquência ${ }^{47}$.

Por fim, um estudo feito há alguns anos no estado de Illinois comprovou que dos vinte e cinco internos no Corredor da Morte, pelo menos treze eram inocentes e, por essa razão, foram postos em liberdade ${ }^{48}$.

Para Vera Regina Pereira de Andrade, o costume da legislação brasileira em resolver os problemas sociais com o Direito Penal, ao invés do Estado assumir seu papel, fazendo cumprir a Constituição, são comuns os recursos à dogmática penal como panacéia de todos os males ${ }^{49}$.

Mais uma evidência de como o sistema da penal capital é falho, um homem norte-americano é inocentado após passar 25 (vinte e cinco) anos no corredor da morte:

Glenn Ford foi condenado à morte por júri formado por brancos em caso de assassinato em que testemunha admitiu ter mentido. Foi preso em 1984 e passou mais de 25 anos no corredor da morte nos Estados Unidos finalmente deixou a prisão após sua condenação pelo assassinato de um joalheiro, em 1983, ter sido revista. Glenn Ford, de 64 anos, foi condenado pelo assassinato de Isadore Rozeman, que tinha 56 anos na época e para quem ford trabalhava

46 GOMES, Nelci. Mais de 4\% dos condenados à morte nos EUA são inocentes, indica estudo. JusBrasil, maio 2014. Disponível em: <http://nelcisgomes.jusbrasil.com.br/noticias/117938 062/mais-de-4-dos-condenados-a-morte-nos-eua-sao-inocentes-indica-estudo?ref=home >. Acesso em: 27 maio 2015.

47 GARCIA, Cláudia Viana. Sanções mais duras reduzem a taxa de criminalidade? Postado em: 26 dez. 2011. Disponível em: <http://www.fatonotorio.com.br/artigos/ver/116/sancoesmais-duras-redu zem-a-taxa-de-criminalidade>. Acesso em: 13 mar. 2015.

48 GARCIA, Cláudia Viana. Sanções mais duras reduzem a taxa de criminalidade? Postado em: 26 dez. 2011. Disponível em: <http://www.fatonotorio.com.br/artigos/ver/116/sancoesmais-duras-redu zem-a-taxa-de-criminalidade>. Acesso em: 13 mar. 2015.

49 ANDRADE, Vera Regina Pereira de. Sistema penal máximo x cidadania mínima: códigos de violência na era da globalização. Porto Alegre: Livraria do Advogado, 2003, p. 22. 
SILVA, Andrey Gastaldi. HEIL, Danielle Mariel. Paralelismo da legislação do modelo Common Law sobre a pena de morte e a redução da maioridade penal no ordenamento jurídico brasileiro. Revista Eletrônica Direito e Política, Programa de Pós-Graduação Stricto Sensu em Ciência Jurídica da UNIVALI, Itajaí, v.11, n.3, $3^{\circ}$ quadrimestre de 2016. Disponível em: www.univali.br/direitoepolitica - ISSN 1980-7791

$$
\text { ocasionalmente } e^{50}
$$

Desta forma, resta evidente a relevância deste tema na pauta das discussões brasileiras e mundiais.

Nesse sentido é o pensamento de Eugenio Raúl Zaffaroni e José Henrique Pierangeli, ao se referirem à pena capital:

Não se trata de uma pena, mas de um simples impedimento físico, como amputar uma mão do batedor de carteiras ou erguer um muro que impeça o avanço de pedestres e veículos. Seu tratamento já não é atribuição do direito penal, restando examinar se é admissível para o resto da ordem jurídica ${ }^{51}$.

Discorrendo sobre o assunto e destacando a impossibilidade de coexistência do direito à vida e a pena de morte, José Afonso da Silva preceitua:

Ao direito à vida contrapõe-se a pena de morte. Uma constituição que assegure o direito à vida incidirá em irremediável incoerência se admitir a pena de morte, é da tradição do Direito Constitucional brasileiro vedá-la, admitida só no caso de guerra externa declarada, nos termos do art. 84, XIX (art. 50, XLVII, a), porque, aí, a Constituição tem que a sobrevivência da nacionalidade é um valor mais importante do que a vida individual de quem porventura venha a trair a pátria em momento cruciante ${ }^{52}$.

Fica à cargo de Norberto Bobbio a ultima ratio:

O Estado não pode colocar-se no mesmo plano do indivíduo singular. $O$ indivíduo age por raiva, por paixão, por interesse, em defesa própria. O Estado responde de modo mediato, reflexivo, racional: Também ele tem o direito de se defender. Mas é muito mais forte do que o indivíduo singular e, por isso, não tem necessidade de tirar a vida desse indivíduo

50 G1. GLOBO. Americano é inocentado após passar 25 anos no corredor da morte. Postado em: 12 mar. 2014. Disponível em: <http://g1.globo.com/mundo/noticia/2014/03/ameri cano-einocentado-apos-passar-25-anos-no-corredor-da-morte.html>. Acesso em: 20 maio 2015.

51 ZAFFARONI, Eugenio Raúl; PIERANGELI, José Henrique. Manual de Direito Penal brasileiro: parte geral. 4. ed. rev. São Paulo: Revista dos Tribunais, 2002, p. 784.

52 SILVA, José A. da. Curso de Direito Constitucional Positivo. 24. ed. São Paulo: Malheiros, 2005, p. 200-201. 
SILVA, Andrey Gastaldi. HEIL, Danielle Mariel. Paralelismo da legislação do modelo Common Law sobre a pena de morte e a redução da maioridade penal no ordenamento jurídico brasileiro. Revista Eletrônica Direito e Política, Programa de Pós-Graduação Stricto Sensu em Ciência Jurídica da UNIVALI, Itajaí, v.11, n.3, $3^{\circ}$ quadrimestre de 2016. Disponível em: www.univali.br/direitoepolitica - ISSN 1980-7791

para se defender. O Estado tem o privilégio e o benefício do monopólio da força ${ }^{53}$.

Uma das diferenças entre o direito do sistema anglo-saxão e o brasileiro é no que se refere à pena de morte, permitida no Brasil apenas em tempo de guerra, já nos Estados Unidos é permitida a crimes civis em vários de seus Estados.

\section{BRASIL E A PENA DE MORTE}

No atual contexto mundial, marcado muitas vezes pela ausência de perspectivas causadas pela repercussão de uma crise socioeconômica, a insegurança geral, a perda de referenciais éticos e morais com altos níveis de corrupção e violência, talvez crie na população uma sensação de que o agravamento das reprimendas é ferramenta hábil para combater a criminalidade, o que já se verificou não ser o que a experiência de outro país demonstra.

A pena de morte não faz parte da tradição jurídica republicana brasileira, conforme ensina Mello:

A história da pena de morte no Brasil teve sua última execução em 1876, determinada pela Justiça Civil, do escravo Francisco, em Pilar das Alagoas, em 1876. A última execução de um homem livre ocorreu em 1861, em Brejo de Areia, na Paraíba. E com a exceção da condenação do escritor Gerardo Mello, em 1942, por crime de espionagem, não há notícias de outras condenações no Brasil $^{54}$.

A Constituição Brasileira de 05 de Outubro de 1988 marca a redemocratização do país, através de um texto socialmente avançado, a Constituição privilegia os Direitos Fundamentais da pessoa humana.

A atual Constituição do Brasil, que foi promulgada em 1988, fortaleceu a

\footnotetext{
${ }^{53}$ BOBBIO, Norberto. A era dos Direitos. Rio de Janeiro: Elsevier, 2004, p. 161.

${ }^{54}$ MELLO, Mônica Barbosa Martins. A pena de morte à luz dos Direitos Humanos e do Direito Constitucional. 2008. Dissertação (Mestre em Direito Constitucional) - Programa de PósGraduação em Direito, Fortaleza, Ceará, 2008. Disponível em:<http://www.ibamendes. com/2011/05/pena-de-morte-no-brasil.html>. Acesso em: 14 abr. 2015.
} 
SILVA, Andrey Gastaldi. HEIL, Danielle Mariel. Paralelismo da legislação do modelo Common Law sobre a pena de morte e a redução da maioridade penal no ordenamento jurídico brasileiro. Revista Eletrônica Direito e Política, Programa de Pós-Graduação Stricto Sensu em Ciência Jurídica da UNIVALI, Itajaí, v.11, n.3, $3^{\circ}$ quadrimestre de 2016. Disponível em: www.univali.br/direitoepolitica - ISSN 1980-7791

proibição da pena capital com a inclusão dessa proibição nos 'Direitos e Garantias Fundamentais':

Art. 50 Todos são iguais perante a lei, sem distinção de qualquer natureza, garantindo-se aos brasileiros e aos estrangeiros residentes no País a inviolabilidade do direito à vida, à liberdade, à igualdade, à segurança e à propriedade, nos termos seguintes:

$[\ldots]$

XLVII - não haverá penas:

a) de morte, salvo em caso de guerra declarada, nos termos do art. $84, \mathrm{XIX}^{55}$;

Tal regra, como demonstra o artigo retro citado, apresenta uma única exceção, no caso de o Brasil declarar guerra a país estrangeiro (art. 84, XIX, CF).

A Constituição Brasileira, não só proíbe que a lei infraconstitucional venha estabelecer a pena de morte no seu artigo 50, inciso XLVII, como também, e o que é de grande importância, proíbe que seja objeto de deliberação a proposta da emenda à Constituição que vise estabelecer a pena de morte.

Portanto, nem através da emenda à Constituição poderá ser recriado o instituto da pena de morte no Brasil, pois o artigo 60, § 40, da Constituição Federal transformou todos os direitos e garantias individuais em cláusulas pétreas da Constituição, imodificáveis mesmo através da emenda.

Esse núcleo imutável está previsto no parágrafo $4^{\circ}$ do art. 60 da Constituição brasileira, a seguir transcrito:

Art. 60 - A Constituição poderá ser emendada mediante proposta: $[\ldots]$

$\S 40$ - Não será objeto de deliberação a proposta de emenda tendente a abolir:

$[\ldots]$

55 BRASIL. Constituição (1988). Constituição da República Federativa do Brasil. Brasília, DF: Senado, 1988, p. 06. Disponível em: <http://www.senado.gov.br/legislacao/const/con1988/ con1988_05.10.1988/con1988.pdf>. Acesso em: 14 jun. 2015. 
SILVA, Andrey Gastaldi. HEIL, Danielle Mariel. Paralelismo da legislação do modelo Common Law sobre a pena de morte e a redução da maioridade penal no ordenamento jurídico brasileiro. Revista Eletrônica Direito e Política, Programa de Pós-Graduação Stricto Sensu em Ciência Jurídica da UNIVALI, Itajaí, v.11, n.3, $3^{\circ}$ quadrimestre de 2016. Disponível em: www.univali.br/direitoepolitica - ISSN 1980-7791

$$
\text { IV - os direitos e garantias individuais }{ }^{56} \text {. }
$$

Essas prescrições de imutabilidade do supracitado parágrafo 40 são as verdadeiras "cláusulas pétreas", conforme se infere a seguir:

Assim, cláusulas pétreas, como o próprio nome sugere, são aquelas cujas matérias o Constituinte Originário gravou como impossíveis de serem abolidas por meio de emenda constitucional, ou seja, por meio de deliberação do Constituinte Derivado. Vê-se que o Constituinte Originário tratou tais matérias com bastante zelo, considerando-as o espírito e a base da nossa Carta Política de 1988, por isso impossíveis de serem abolidas ou restringidas ${ }^{57}$.

Portanto, na Constituição da República Federativa do Brasil, a proibição da pena de morte (artigo $5^{\circ}$ ) compõe o Título II, referente aos Direitos e Garantias Fundamentais, o que a inclui entre os direitos constitucionais indisponíveis.

Nesse mesmo sentido:

O exame da admissibilidade de uma proposta de emenda à Constituição que convoque plebiscito para decidir sobre a adoção da pena de morte remete ao exame das limitações materiais que a Constituição da República impõe ao Poder de Reforma, através da chamada 'cláusula pétrea', tradição republicana que veda a deliberação sobre propostas de emenda tendentes a abolir determinados princípios nucleares da ordem constitucional ${ }^{58}$.

Da mesma forma, sobre o direito à vida:

Está inscrito no capítulo inviolável das garantias individuais da Constituição Federal e é assegurado pela Convenção Americana de Direitos Humanos - o chamado Pacto de São

56 BRASIL. Constituição (1988). Constituição da República Federativa do Brasil. Brasília, DF: Senado, 1988, p. 06. Disponível em: <http://www.senado.gov.br/legislacao/const/con1988/ con1988_05.10.1988/con1988.pdf>. Acesso em: 14 jun. 2015.

57 LEITE, Arypson Silva. Impossibilidade constitucional de implantação da pena de morte no Brasil para os crimes comuns. Âmbito Jurídico, Rio Grande, XV, n. 102, jul. 2012. Disponível em: <http://www.ambito-juridico.com.br/site/index.php/?n_link=revista_artigos_leitu ra\&artigo_id=12002\&revista_caderno=9>. Acesso em: 02 maio 2015.

58 REVISTA ÂMBITO JURÍDICO. O debate da pena de morte: seus defensores e opositores. Disponível em: <http://www.ambito-juridico.com.br/pdfsGerados/artigos/3430.pdf>. Acesso em: 11 mar. 2015. 
SILVA, Andrey Gastaldi. HEIL, Danielle Mariel. Paralelismo da legislação do modelo Common Law sobre a pena de morte e a redução da maioridade penal no ordenamento jurídico brasileiro. Revista Eletrônica Direito e Política, Programa de Pós-Graduação Stricto Sensu em Ciência Jurídica da UNIVALI, Itajaí, v.11, n.3, $3^{\circ}$ quadrimestre de 2016. Disponível em: www.univali.br/direitoepolitica - ISSN 1980-7791

José, recentemente subscrito pelo governo brasileiro. Essas são premissas do Estado de Direito democrático incompatíveis com a proposta de pena de morte ${ }^{59}$.

A Convenção Americana sobre Direitos Humanos (Pacto de São José), celebrado em São José da Costa Rica, em 22 de novembro de 1969, ao cuidar do direito à vida, proíbe aos Estados Membros a extensão da aplicação da pena de morte a delitos aos quais não se aplique atualmente e determina a impossibilidade de restabelecê-la nos Estados que a tenham abolido ${ }^{60}$.

Ademais, em se tratando de direitos humanos (e a vedação à pena de morte se insere nesse contexto), insta salientar que os tratados internacionais que tenham por objeto a disciplina daqueles direitos poderão alcançar o mesmo grau de eficácia e rigidez das normas constitucionais, uma vez que, segundo o $\S 3^{\circ}$, do artigo 50, da Constituição Federal (incluído pela Emenda Constitucional no 45, de 2004):

Os tratados e convenções internacionais sobre direitos humanos que forem aprovados, em cada Casa do Congresso Nacional, em dois turnos, por três quintos dos votos dos respectivos membros, serão equivalentes às emendas constitucionais ${ }^{61}$.

Além disso, os demais direitos humanos, só poderão ser efetivamente exercitados se o ser humano estiver vivo. Nesse sentido, impende anotar as seguintes palavras sobre o direito à vida escritas por José Afonso da Silva: "A vida humana, que é objeto do direito assegurado no art. 50, caput, integra-se de elementos materiais (físicos e psíquicos) e imateriais (espirituais), por isso que ela é constituída como fonte primária dos outros bens jurídicos" ${ }^{\prime 62}$.

59 BIERRENBACH, Maria Ignês de Souza. A favor da vida: contra a pena de morte. São Paulo: Cortez, 1993, p. 34.

60 REVISTA ÂMBITO JURÍDICO. O debate da pena de morte: seus defensores e opositores. Disponível em: <http://www.ambito-juridico.com.br/pdfsGerados/artigos/3430.pdf>. Acesso em: 11 mar. 2015.

61 BRASIL. Constituição (1988). Constituição da República Federativa do Brasil. Brasília, DF: Senado, 1988, p. 07. Disponível em:<http://www.senado.gov.br/legislacao/const/con1988/con 1988_05.10.1988/con1988.pdf>. Acesso em: 14 jun. 2015.

62 SILVA, José Afonso da. Curso de Direito Constitucional Positivo. 24. ed. São Paulo: 
SILVA, Andrey Gastaldi. HEIL, Danielle Mariel. Paralelismo da legislação do modelo Common Law sobre a pena de morte e a redução da maioridade penal no ordenamento jurídico brasileiro. Revista Eletrônica Direito e Política, Programa de Pós-Graduação Stricto Sensu em Ciência Jurídica da UNIVALI, Itajaí, v.11, n.3, $3^{\circ}$ quadrimestre de 2016. Disponível em: www.univali.br/direitoepolitica - ISSN 1980-7791

A vida, portanto, nos ensinamentos de Erival da Silva Oliveira e Gustavo Goldzveig, é pressuposto indispensável para que os demais direitos sejam fruídos e tutelados. Dessa forma, é dever do Estado agir sempre de modo a tutelar o direito à vida ${ }^{63}$.

Como no Brasil só a existe a previsão da referida pena para crimes militares em tempo de guerra, não poderia ser estendida nem restabelecida aos crimes comuns, pelos motivos elencados anteriormente, bem como pela adesão do Brasil ao supramencionado Pacto, o que constitui obstáculo definitivo ao retorno da referida pena.

Ainda sobre o Pacto de São José, importante ressaltar acerca da vedação ao retrocesso, a qual se trata da teoria cuja proteção aos direitos humanos somente pode ser aumentada, ampliada, nunca restringida ${ }^{64}$.

No mais, cumpre ressaltar que o Brasil assinou na data de 07 de junho de 1994, o Decreto n.o 2.754, de 27 de agosto de 1998, que promulgou o Protocolo Adicional à Convenção Americana sobre Direitos Humanos referente à Abolição da Pena de Morte, adotado em Assunção, em 08 de junho de 1990, no qual consta:

[...] Que o artigo 4 da Convenção Americana sobre Direitos Humanos reconhece o direito à vida e restringe a aplicação da pena de morte;

Que toda pessoa tem o direito inalienável de que se respeite sua vida, não podendo este direito ser suspenso por motivo algum;

Que a tendência dos Estados americanos é favorável à abolição da pena de morte; $[\ldots]^{65}$.

Malheiros, 2005, p. 198.

63 OLIVEIRA, Erival da Silva; GOLDZVEIG, Gustavo. Comentários à convenção americana de Direitos Humanos. São Paulo: ACJ, 2012, p. 39.

64 OLIVEIRA, Erival da Silva; GOLDZVEIG, Gustavo. Comentários à convenção americana de Direitos Humanos. São Paulo: ACJ, 2012, p. 43.

65 BRASIL. Presidência da República. Decreto n. 2.754, de 27 de agosto de 1998. Disponível em: 
SILVA, Andrey Gastaldi. HEIL, Danielle Mariel. Paralelismo da legislação do modelo Common Law sobre a pena de morte e a redução da maioridade penal no ordenamento jurídico brasileiro. Revista Eletrônica Direito e Política, Programa de Pós-Graduação Stricto Sensu em Ciência Jurídica da UNIVALI, Itajaí, v.11, n.3, $3^{\circ}$ quadrimestre de 2016. Disponível em: www.univali.br/direitoepolitica - ISSN 1980-7791

Portanto, a pena de morte no Brasil só é possível em caso de guerra declarada, conforme dispõe a Constituição da República e deve ser executada de acordo com o Código Penal Militar e Código de Processo Penal Militar:

A pena capital somente poderá ser aplicada em tempo de guerra, que deverá ser declarada pelo Presidente da República, nos casos previstos em lei. O Código Penal Militar (CPM) admite a aplicação da pena de morte quando forem praticados determinados crimes, como a espionagem, a traição, entre outros. A pena de morte será aplicada na modalidade de fuzilamento, devendo ser assegurado ao acusado a ampla defesa e o contraditório ${ }^{66}$.

Deste modo, fora esse caso permitido pela Constituição Federal, caso de guerra declarada, somente com uma nova Constituição é que seria possível aumentar as hipóteses de pena de morte no Brasil.

Por fim, restam as palavras de Miguel Reale, citado por Anderson Real Soares e Domingos Napolitano Júnior, que, contrário àquela pena, argumentava "não sou favorável à pena de morte, porque a morte é inexplicável. Não sei como se pode transformar a morte em pena"67.

\section{REDUÇÃO DA MAIORIDADE PENAL NO BRASIL}

Cumpre destacar que no âmbito do ordenamento jurídico brasileiro, além da pena de morte ser um caso de exceção, os menores de 18 (dezoito) anos são considerados inimputáveis, razão pela qual a eles não se aplica as penas e sanções do Código Penal, mas sim as medidas previstas no Estatuto da Criança e do Adolescente (ECA - Lei n.o 8.069/90), tendo recentemente a Câmara dos

<http://www.planalto.gov.br/ccivil_03/decreto/D2754.htm>. Acesso em: 14 maio 2015.

${ }^{66}$ ROSA, Paulo Tadeu Rodrigues; MACEROU, Eliane Ferreira. Pena de morte ou prisão perpétua: uma solução justa? Postado em: 26 fev. 2002. Disponível em: <http://www.ibccrim. org.br>. Acesso em: 23 abr. 2015.

${ }^{67}$ SOARES, Anderson Real; NAPOLITANO JÚNIOR, Domingos. Uma análise sobre a pena de morte. Jornal do Advogado, OABSP, n. 305, p. 1-7, abr. 2006. Disponível em: <http://www. uniesp.edu.br/guaruja/site/revista/revistaEdicao5Numero1/PDfs/artigo05_uma\%C3\%A1liseSobre PenaMorte.pdf>. Acesso em: 15 mar. 2015. 
SILVA, Andrey Gastaldi. HEIL, Danielle Mariel. Paralelismo da legislação do modelo Common Law sobre a pena de morte e a redução da maioridade penal no ordenamento jurídico brasileiro. Revista Eletrônica Direito e Política, Programa de Pós-Graduação Stricto Sensu em Ciência Jurídica da UNIVALI, Itajaí, v.11, n.3, $3^{\circ}$ quadrimestre de 2016. Disponível em: www.univali.br/direitoepolitica - ISSN 1980-7791

Deputados aprovado votação da proposta de redução da maioridade penal (Proposta de Emenda à Constituição no 171, de 1993) por um texto mais brando que reduz de 18 para 16 anos a idade mínima para a imputação penal em casos de crimes hediondos, homicídio doloso e lesão corporal seguida de morte.

A criminalidade juvenil no Brasil torna-se tema que ganha forte repercussão quando jovens menores de 18 anos cometem crimes violentos contra a vida, colocando em risco a segurança da sociedade.

Em relação à criminalidade envolvendo menores, crescem as opiniões acerca da mudança na legislação brasileira, quanto à redução da imputabilidade penal, conferindo nova redação ao artigo 228 da Constituição da República de 1988, porquanto se observa atualmente:

Existem no Congresso Nacional 29 Propostas de Emenda à
Constituição, elaboradas para viabilizar a modificação da
faixa etária de responsabilização penal, uma vez que os
menores estão sujeitos à legislação especial, Estatuto da
Criança e do Adolescente, cumprindo medidas
socioeducativas, por serem considerados inimputáveis. O
ECA considera como criança a pessoa de até 12 anos de
idade incompletos, e adolescentes entre 12 e 18 anos de
idade, conforme definição do seu art. $2^{68}$.

Quanto à aprovação, em primeiro turno, na Câmara dos Deputados, no dia 02 de julho do corrente, de emenda aglutinativa à PEC 171/93, apesar da rejeição da mesma matéria na votação do dia anterior, foi apresentada nota de repúdio pela ABMP - Associação Brasileira de Magistrados, Promotores de Justiça e Defensores Públicos da Infância e da Juventude, São Paulo - SP:

O procedimento adotado para tal aprovação fere o regimento interno daquela casa e norma expressa da Constituição no seu artigo 60, parágrafo 5, eivando de vício formal a proposta. Destaca, mais uma vez, que a idade penal, prevista no art. 228 da Constituição Federal, é cláusula pétrea, e, portanto, não pode ser objeto de emenda, nos termos do art. 60 , parágrafo $4^{\circ} \mathrm{c} / \mathrm{c}$ art. $5^{\circ}$, parágrafo $2^{\circ}$, do texto constitucional, o que, por sua vez, demonstra a

68 REVISTA DE DIREITOS E GARANTIAS FUNDAMENTAIS. Faculdade de Direito de Vitória - FDV, Vitória, jan./jun. 2013, p. 194. (Direito - Periódicos). 
SILVA, Andrey Gastaldi. HEIL, Danielle Mariel. Paralelismo da legislação do modelo Common Law sobre a pena de morte e a redução da maioridade penal no ordenamento jurídico brasileiro. Revista Eletrônica Direito e Política, Programa de Pós-Graduação Stricto Sensu em Ciência Jurídica da UNIVALI, Itajaí, v.11, n.3, $3^{\circ}$ quadrimestre de 2016. Disponível em: www.univali.br/direitoepolitica - ISSN 1980-7791

inconstitucionalidade material da emenda. A redução da idade penal não pode ocorrer a qualquer custo, máxime com o desrespeito a institutos legais claros, aqui mencionados, configurando inaceitáveis insegurança jurídica e retrocesso em garantias fundamentais. Não se pode deixar de frisar, que essa proposta não resolverá a causa da violência na nossa sociedade, mas serve como alerta urgente a todos, sociedade, família e estado, da necessidade de união de esforços para uma política séria, coletiva e compromissada com o desenvolvimento regular do público infantojuvenil ${ }^{69}$.

Segundo Marcelo Gomes Silva, a cultura do medo que se criou em torno da criminalidade provoca um generalizado desejo de punição, uma intensa busca por repressão e obsessão por segurança, pois a lei passa a ser a "tábua de salvação" da sociedade e, quanto maior for a sua dureza, mais satisfeita ela estará70.

Essa mesma linha de raciocínio de cultura punitiva é trazida para o Direito da Criança e do Adolescente:

A reflexão sobre o ingresso dos jovens no universo de contextos de violência muitas vezes não leva em consideração a realidade social de pobreza a que está submetida a maioria da população juvenil. Dados relevantes demonstram que os jovens no Brasil são o grupo mais afetado pelos homicídios, principalmente, os do sexo masculino, revelando-se que, nos últimos 15 anos, houve um dramático crescimento nos assassinatos perpetrados contra crianças e adolescentes. Por isso, resulta-se sustentar que os adolescentes são muito mais vítimas de crimes do que autores $^{71}$.

Cumpre registrar que a expansão da política do encarceramento em massa no mundo surgiu com mais força nos Estados Unidos, durante o período dos anos

${ }^{69}$ Associação Brasileira de Magistrados, Promotores de Justiça e Defensores Públicos da Infância e da Juventude. Rua Boa Vista, 76 - 2.andar - Centro - São Paulo - SP - CEP: 01014-000 Telefone: 3180-3972 secretaria@abmp.org.br CNPJ: 00.246.533/0001-58 www.abmp.org.br. (Disponível em: http://emporiododireito.com.br/nota-de-repudio-da-abmp-a-aprovacao-deemenda-aglutinativa-a-pec-17193-na-camara-dos-deputados/. Acesso em: 13 jul. 2015.)

70 SILVA, Marcelo Gomes. Menoridade penal: uma visão sistêmica. Rio de Janeiro. Lumen Juris, 2012, p. 106.

${ }^{71}$ REVISTA DE DIREITOS E GARANTIAS FUNDAMENTAIS. Faculdade de Direito de Vitória - FDV, Vitória, jan./jun. 2013, p. 194. (Direito - Periódicos). 
SILVA, Andrey Gastaldi. HEIL, Danielle Mariel. Paralelismo da legislação do modelo Common Law sobre a pena de morte e a redução da maioridade penal no ordenamento jurídico brasileiro. Revista Eletrônica Direito e Política, Programa de Pós-Graduação Stricto Sensu em Ciência Jurídica da UNIVALI, Itajaí, v.11, n.3, $3^{\circ}$ quadrimestre de 2016. Disponível em: www.univali.br/direitoepolitica - ISSN 1980-7791

80, depois da queda da economia americana do governo Reagan, entre 1981 a 1988. Aguardavam na lista de execução nas prisões americanas 2.802 pessoas das quais eram afro-americanas 1.102 , oriundas das classes pobres ${ }^{72}$.

Hoje, portanto, ainda que o sistema penal brasileiro privilegie induvidosamente o encarceramento, para Mirabete:

A redução da maioridade penal não é a solução para os problemas derivados da criminalidade infantil, visto que o cerne do problema da criminalidade se reluz em decorrência das condições socialmente degradantes e economicamente opressivas que expõe enorme contingente de crianças e adolescentes, em nosso país, à situação de injusta marginalidade social ${ }^{73}$.

Ademais, a pretensão da redução viola o disposto no artigo 41 da Convenção das Nações Unidas de Direito da Criança, onde está implícito que os signatários não tornarão mais grave a lei interna de seus países, em face do contexto normativo da Convenção, a qual se faz lei interna de caráter constitucional, conforme o $\S$ 2.0 do artigo $5 .^{\circ}$ da Constituição Federal ${ }^{74}$.

Não bastasse isso, o legislador constitucional incorporou tratamento especial às crianças e adolescentes, como pessoas em desenvolvimento, atribuindo-lhes direitos fundamentais que estão expressamente previstos nos arts. 227 e 228 da Constituição $^{75}$.

Para Ana Beatriz Barboza Silva, a necessidade de adotar uma idade penal mínima tem como base a ideia de que crianças e até mesmo adolescentes não possuem

\footnotetext{
72 REVISTA DE DIREITOS E GARANTIAS FUNDAMENTAIS. Faculdade de Direito de Vitória - FDV, Vitória, jan./jun. 2013, p. 194. (Direito - Periódicos).

73 MIRABete, J. F. Manual de Direito Penal: parte geral. 27. ed. São Paulo: Atlas, 2012, v. 1, p. 217.

74 REVISTA DE DIREITOS E GARANTIAS FUNDAMENTAIS. Faculdade de Direito de Vitória - FDV, Vitória, jan./jun. 2013, p. 194. (Direito - Periódicos).

75 REVISTA DE DIREITOS E GARANTIAS FUNDAMENTAIS. Faculdade de Direito de Vitória - FDV, Vitória, jan./jun. 2013, p. 194. (Direito - Periódicos).
} 
SILVA, Andrey Gastaldi. HEIL, Danielle Mariel. Paralelismo da legislação do modelo Common Law sobre a pena de morte e a redução da maioridade penal no ordenamento jurídico brasileiro. Revista Eletrônica Direito e Política, Programa de Pós-Graduação Stricto Sensu em Ciência Jurídica da UNIVALI, Itajaí, v.11, n.3, $3^{\circ}$ quadrimestre de 2016. Disponível em: www.univali.br/direitoepolitica - ISSN 1980-7791

discernimento completo sobre o certo e o errado, bem como ainda não desenvolveram controle adequado sobre seus impulsos ${ }^{76}$.

A questão principal que envolve a temática é se ao estabelecer a idade mínima de imputabilidade penal, a norma inscrita no art. 228 do texto constitucional integra ou não o núcleo imodificável da Carta Magna, pois em caso afirmativo, se constitui cláusula pétrea e, portanto, não estaria sujeito à modificação por emenda à Constituição, e em caso negativo, poderia ser objeto de Proposta de Emenda Constitucional.

O ministro da Justiça, José Eduardo Cardozo, entende que não pode haver referida alteração:

A Constituição prevê inimputabilidade penal até os 18 anos de idade. É um direito consagrado e uma cláusula pétrea da Constituição do Brasil. Nem mesmo uma emenda pode mudar isso. Qualquer tentativa de redução é inconstitucional. Essa é uma discussão descabida do ponto de vista jurídico, disse Cardozo, em entrevista ao jornal $O$ Estado de S. Paulo, em 29 de abril. Diminuir a idade penal não só não reduz a criminalidade como pode agravar ainda mais o problema, excluindo muitos que quase já não têm direitos ${ }^{77}$.

Desta feita, as matérias incluídas nas cláusulas de irreformabilidade do art. 60, $\S 40$, I ao IV, são improponíveis ao Congresso Nacional, decorrendo que qualquer tentativa do legislador infraconstitucional de abolir do texto constitucional a fixação da idade penal ou a que mesmo pretenda reduzir a idade de responsabilização penal será, flagrantemente, inconstitucional ${ }^{78}$.

Para fazer um paralelo com a questão da juventude que comete crimes no Brasil e nos Estados norte-americanos, vale ressalvar o afirmado por Pazzian: "nos

76 SILVA, Ana Beatriz Barbosa. Mentes perigosas: o psicopata mora ao lado. Rio de Janeiro: Objetiva, 2008, p. 143-144.

77 FARIA, Glauco. Redução da maioridade: ilusão e oportunismo. Revista Fórum, 12 jun. 2013. Disponível em: <http://revistaforum.com.br/blog/2013/06/reducao-da-maioridade-ilusao-e-opor tunismo/>. Acesso em: 14 maio 2015.

78 REVISTA DE DIREITOS E GARANTIAS FUNDAMENTAIS. Faculdade de Direito de Vitória - FDV, Vitória, jan./jun. 2013, p. 194. (Direito - Periódicos). 
SILVA, Andrey Gastaldi. HEIL, Danielle Mariel. Paralelismo da legislação do modelo Common Law sobre a pena de morte e a redução da maioridade penal no ordenamento jurídico brasileiro. Revista Eletrônica Direito e Política, Programa de Pós-Graduação Stricto Sensu em Ciência Jurídica da UNIVALI, Itajaí, v.11, n.3, $3^{\circ}$ quadrimestre de 2016. Disponível em: www.univali.br/direitoepolitica - ISSN 1980-7791

presídios dos Estados Unidos com relação aos menores de idade, muitos reclusos são sentenciados a cumprir penas em prisões para adultos"179.

Já no tocante a orientação da Organização das Nações Unidas com relação à idade mínima para a responsabilidade penal:

A ONU sugere que a idade mínima da responsabilidade penal não seja muito baixa, embora não faça uma recomendação específica, mas ressalta que é preciso levar em conta os fatores de maturidade intelectual e emocional. As ponderações e o trabalho do Comitê sobre Direitos da Criança do órgão fez com que muitos países elevassem esse limite. Em 1977, Israel mudou a idade de responsabilização de 9 para 13 anos; em 1979, Cuba aumentou de 12 para 16; em 1983, a Argentina alterou de 14 para 16; em 1987, a Noruega mudou de14 para 15 e, em 2001, a Espanha elevou de 12 para 14 anos. Todos com uma idade mínima acima dos 12 anos estabelecidos pela lei brasileira ${ }^{80}$.

Importante mencionar dados destacados por Bocato e emitidos pela Unicef:

De 53 países, sem contar o Brasil, temos que 42 deles (79\%) adotam a maioridade penal aos 18 anos ou mais. Esta fixação majoritária decorre das recomendações internacionais que sugerem a existência de um sistema de justiça especializado para julgar, processar e responsabilizar autores de delitos abaixo dos 18 anos. Em outras palavras, no mundo todo a tendência é a implantação de legislações e justiças especializadas para os menores de 18 anos, como é o caso brasileiro ${ }^{81}$.

Nas palavras de Marcelo Gomes Silva, no tocante as Propostas de Emendas à Constituição que tramitam atualmente no Congresso Nacional brasileiro tendentes a reduzir a imputabilidade penal, "é importante que fique consignado o

79 PAZZIAN, Roberta Mucare. A descaracterização da prisão como forma de ressocializar o indivíduo. Postado em: 2012. Disponível em: <http://www.conamp.org.br/Lists/artigos/Disp Form.aspx?ID=220\&Source=/>. Acesso em: 12 abr. 2015.

80 FARIA, Glauco. Redução da maioridade: ilusão e oportunismo. Revista Fórum, 12 jun. 2013. Disponível em: <http://revistaforum.com.br/blog/2013/06/reducao-da-maioridade-ilusao-e-opor tunismo/>. Acesso em: 14 maio 2015.

81 BOCATO, Vinícius. Razões para não reduzir a maioridade penal. Postado em: 16 abr. 2013. Disponível em: <http://www.revistaforum.com.br/blog/2013/04/razoes-para-nao-reduzir-amaiorida de-penal/>. Acesso em: 10 maio 2015. 
SILVA, Andrey Gastaldi. HEIL, Danielle Mariel. Paralelismo da legislação do modelo Common Law sobre a pena de morte e a redução da maioridade penal no ordenamento jurídico brasileiro. Revista Eletrônica Direito e Política, Programa de Pós-Graduação Stricto Sensu em Ciência Jurídica da UNIVALI, Itajaí, v.11, n.3, $3^{\circ}$ quadrimestre de 2016. Disponível em: www.univali.br/direitoepolitica - ISSN 1980-7791

absurdo retrocesso humanitário das propostas supracitadas, na contramão de todas as diretrizes internacionais" ${ }^{\prime \prime 2}$.

O Brasil já viveu a experiência de reduzir a idade para imputação penal a fim de acalmar o clamor popular, conforme lembra Alexandre Morais da Rosa:

A Lei 5.258 de 10 de abril de 1967, substituiu a Lei de Emergência (Decreto-Lei n. 6.026 de 24/11/43), que adequava o Código de Menores (1927) ao Código Penal (1940). O Diploma legislativo foi oriundo do caso 'Aída Cury' quando da participação de um adolescente na morte de uma estudante. A Lei foi revogada em maio do ano seguinte, apenas 13 meses depois de sua entrada em vigor, pela Lei 5.439 , de 22 de maio de $1968^{83}$.

Assim, segundo Silva, a própria história nos mostra que todas as legislações produzidas sob o clamor popular, tempos após são abrandadas, ora por inconstitucionalidade, ora por ineficácia, o que só demonstra que legislar para agradar a opinião pública é muito mais fácil do que resolver os problemas estruturais $^{84}$.

A redução da maioridade penal não resolve nem ameniza o problema da violência, como preconiza Bocato:

'Toda a teoria científica está a demonstrar que ela [a redução] não representa benefícios em termos de segurança para a população', asseverou em fevereiro Marcos Vinícius Furtado, presidente da OAB. A discussão em torno na maioridade penal só desvia o foco das verdadeiras causas da violência ${ }^{85}$.

82 SILVA, Marcelo Gomes. Menoridade penal: uma visão sistêmica. Rio de Janeiro. Lumen Juris, 2012, p. 23.

83 ROSA, Alexandre Morais da. Redução da idade penal: "vale a pena ver de novo?" In: VALLE, Juliano Keller do; MARCELINO JÚNIOR, Júlio César. Reflexões da pós modernidade: Estado, Direito e Constituição. Florianópolis: Conceito Editorial, 2008, p. 16.

${ }^{84}$ SILVA, Marcelo Gomes. Menoridade penal: uma visão sistêmica. Rio de Janeiro. Lumen Juris, 2012, p. 24.

85 BOCATO, Vinícius. Razões para não reduzir a maioridade penal. Postado em: 16 abr. 2013. Disponível em: <http://www.revistaforum.com.br/blog/2013/04/razoes-para-nao-reduzir-amaiorida de-penal/>. Acesso em: 10 maio 2015. 
SILVA, Andrey Gastaldi. HEIL, Danielle Mariel. Paralelismo da legislação do modelo Common Law sobre a pena de morte e a redução da maioridade penal no ordenamento jurídico brasileiro. Revista Eletrônica Direito e Política, Programa de Pós-Graduação Stricto Sensu em Ciência Jurídica da UNIVALI, Itajaí, v.11, n.3, $3^{\circ}$ quadrimestre de 2016. Disponível em: www.univali.br/direitoepolitica - ISSN 1980-7791

Nos 54 países que reduziram a maioridade penal não se registrou redução da violência. A Espanha e a Alemanha voltaram atrás na decisão de criminalizar menores de 18 anos. Hoje, 70\% dos países estabelecem 18 anos como idade penal mínima ${ }^{86}$.

Assim, depreende-se que a legislação brasileira prevê os instrumentos necessários à proteção dos menores que incidem em conduta considera como crime ou contravenção - ato infracional, assegurando-lhes tratamento especializado e diferenciado em relação aos maiores de 18 (dezoito) anos. Tratase do princípio do melhor interesse da criança e do adolescente ${ }^{87}$.

No mais, vale mencionar a ressalva feita por Nicknich, a qual afirma que dentre todos os ramos do Direito, o que mais necessita da vigilância dos estudiosos da Ciência Jurídica e dos operadores seja o Direito da Criança e do Adolescente, uma vez que os titulares dos bens jurídicos normalmente não possuem a capacidade de defender seus direitos e opiniões, necessitando sempre de alguém que o faça por eles ${ }^{88}$.

Por fim, acerca do flagrante problema estrutural no Brasil, Callado de Oliveira destaca que "uma boa política social é a melhor política criminal, sendo que a restauração deve começar pelo retorno à consciência dos princípios básicos que modelam a Civilização Cristã, perdidos nas brumas das ideologias" ${ }^{89}$.

${ }^{86}$ GOMES, Nelci. Todos os países que reduziram a maioridade penal não diminuíram a violência. Postado em: abr. 2014a. Disponível em: <http://nelcisgomes.jusbrasil.com.br/noti cias/116624331/todos-os-paises-que-reduziram-a-maioridade-penal-nao-diminuiram-aviolencia >. Acesso em: 20 maio 2015.

87 OLIVEIRA, Erival da Silva; GOLDZVEIG, Gustavo. Comentários à convenção americana de Direitos Humanos. São Paulo: ACJ, 2012. p. 56.

88 NICKNICH, Mônica. Ato infracional e poder judiciário: uma análise à luz do princípio da dignidade da pessoa humana. Blumenau: Nova Letra, 2010, p. 176.

89 OLIVEIRA, Gilberto Callado de. Garantismo e barbárie: a face oculta do garantismo penal. São Paulo: Conceito Editorial, 2011, p. 214. 
SILVA, Andrey Gastaldi. HEIL, Danielle Mariel. Paralelismo da legislação do modelo Common Law sobre a pena de morte e a redução da maioridade penal no ordenamento jurídico brasileiro. Revista Eletrônica Direito e Política, Programa de Pós-Graduação Stricto Sensu em Ciência Jurídica da UNIVALI, Itajaí, v.11, n.3, $3^{\circ}$ quadrimestre de 2016. Disponível em: www.univali.br/direitoepolitica - ISSN 1980-7791

\section{CONSIDERAÇÕES FINAIS}

É cediço que o Direito Penal é o ramo mais severo do ordenamento jurídico brasileiro, posto que o mesmo, através de suas penas privativas de liberdade, atingem um dos bens jurídicos mais importantes do homem: a sua liberdade de ir e vir.

Conclui-se da análise da legislação norte-americana, no que concerne a adoção da pena de morte, que um dos países mais ricos do mundo, e que mais executa condenados, paradoxalmente apresenta significativa violência, evidenciando que a utilização da pena capital não logra êxito em seu intento de reprimir os impulsos criminosos.

No mais, foi possível evidenciar que alguns Estados norte-americanos e países aboliram a referida penalidade, porém diversos outros a mantém até os dias atuais, como o caso do Texas.

Portanto, o que se percebe dos Estados Unidos da América, país adepto do common law, que possui a "Capital Mundial das Execuções", ou seja, o Estado do Texas, é que este tende a resolver seus problemas sociais através do Direito Penal, tanto que possui indubitavelmente a maior população carcerária do mundo, e mesmo assim mantém uma criminalidade elevada.

Dos 50 Estados norte-americanos, 31 Estados fazem uso do instituto da pena de morte, porém cada Estado utiliza seu próprio estatuto.

Sobre a consagração da pena de morte no Brasil com a promulgação da Constituição da República Federativa de 1988, há reserva por conta da previsão constitucional em casos de guerra declarada (artigo $5^{\circ}$, inciso XLVII, alínea 'a').

Além do mais, o pacto de San José da Costa Rica ao qual o Brasil aderiu, e a Convenção Americana sobre Direitos do Homem atuam como sólidos obstáculos ao ingresso da medida no ordenamento jurídico brasileiro.

O que se quer dizer é que não há, em pleno século XXI, e mesmo após termos notícias de condenações duvidosas à pena capital, se torna inadmissível a 
SILVA, Andrey Gastaldi. HEIL, Danielle Mariel. Paralelismo da legislação do modelo Common Law sobre a pena de morte e a redução da maioridade penal no ordenamento jurídico brasileiro. Revista Eletrônica Direito e Política, Programa de Pós-Graduação Stricto Sensu em Ciência Jurídica da UNIVALI, Itajaí, v.11, n.3, $3^{\circ}$ quadrimestre de 2016. Disponível em: www.univali.br/direitoepolitica - ISSN 1980-7791

manutenção da pena de morte, seja em qualquer lugar e sob qualquer regime jurídico que for.

A pena de morte é polêmica há séculos, e as discussões que envolvem essa temática não estão findadas. Afinal, a questão da violência jamais encontrará soluções na violência, venha ela de onde vier, do próprio povo ou dos chamados poderes constitucionais, mesmo porque o crime e os criminosos sempre irão existir, queira sim ou não.

No tocante a redução da maioridade penal, de acordo com o exposto no presente artigo, a idade média padrão de maioridade penal na maioria dos países do mundo é de 18 anos. Ademais, é o que se recomenda na Convenção da ONU sobre os Direitos da Criança, de 1989.

Assim, depreende-se que a legislação brasileira prevê os instrumentos necessários à proteção dos menores que incidem em conduta considera como crime ou contravenção - ato infracional, assegurando-lhes tratamento especializado e diferenciado em relação aos maiores de 18 (dezoito) anos.

Logo, resta claro, que a questão principal se encontra em compreender que maximizar o sistema penal e minimizar o sistema social de nada adiantará no combate à criminalidade, por intermédio do agravamento excessivo de reprimendas, com penas mais duradouras ou mais cruéis, pois se estará combatendo somente o efeito, e não a causa, uma vez que o ponto central está na certeza da punição, seja dos adultos, seja dos jovens infratores.

\section{REFERÊNCIAS DAS FONTES CITADAS}

ALMEIDA, Sidney Silva de. O Supremo Tribunal Federal e os efeitos de suas decisões no controle difuso de constitucionalidade. Revista da Esmese, Aracaju, n.16, p. 91-150, 2012.

AMARAL, Carneiro Ariel. Pena de morte. JusBrasil, 2013. Disponível em: <http://carneiro.jusbrasil. com.br/artigos/111686526/pena-de-morte>. Acesso em: 12 mar. 2015.

ANDRADE, Vera Regina Pereira de. Sistema penal máximo x cidadania 
SILVA, Andrey Gastaldi. HEIL, Danielle Mariel. Paralelismo da legislação do modelo Common Law sobre a pena de morte e a redução da maioridade penal no ordenamento jurídico brasileiro. Revista Eletrônica Direito e Política, Programa de Pós-Graduação Stricto Sensu em Ciência Jurídica da UNIVALI, Itajaí, v.11, n.3, $3^{\circ}$ quadrimestre de 2016. Disponível em: www.univali.br/direitoepolitica - ISSN 1980-7791

mínima: códigos de violência na era da globalização. Porto Alegre: Livraria do Advogado, 2003.

BECCARIA, Cesare. Dos delitos e das penas. São Paulo: Martin Claret, 2001.

BIERRENBACH, Maria Ignês de Souza. A favor da vida: contra a pena de morte. São Paulo: Cortez, 1993.

BITTENCOURT, Daniela Almeida. Previsão Constitucional da pena de morte no Brasil e suas implicações no atual contexto global em prol dos Direitos Humanos. Postado em: 2012. Disponível em: <http://www.publicadireito.com.br/ artigos/?cod=1e747ddbea997a1b>. Acesso em: 24 abr. 2015.

BOBBIO, Norberto. A era dos Direitos. Rio de Janeiro: Elsevier, 2004.

BOCATO, Vinícius. Razões para não reduzir a maioridade penal. Postado em: 16 abr. 2013. Disponível em: <http://www.revistaforum.com.br/blog/2013/ 04/razoes-para-nao-reduzir-a-maioridade-penal/>. Acesso em: 10 maio 2015.

BRASIL. Constituição (1988). Constituição da República Federativa do Brasil. Brasília, DF: Senado, 1988, p. 06. Disponível em: <http://www.senado.gov.br/legislacao/const/con1988/ con1988_05.10.1988/con1988.pdf>. Acesso em: 14 jun. 2015.

BRASIL. Presidência da República. Decreto n, 2.754, de 27 de agosto de 1998. Disponível em: <http://www.planalto.gov.br/ccivil_03/decreto/D2754.htm>. Acesso em: 14 maio 2015.

BURNHAM, William. Introduction to the Law and Legal System of the United States. 3. ed. St. Paul, MN: West Group, 2002.

CAMARGO, Marcelo Novelino. Leituras complementares de Direito Constitucional: controle de constitucionalidade. 2. ed. Salvador: JusPodivim, 2008.

CASTRO JÚNIOR, Osvaldo Agripino de. Introdução à história do Direito: Estados Unidos x Brasil. Florianópolis: IBRADD/CESUSC, 2001.

CLEMENTINO, Marco Bruno Miranda. A culpabilidade no Direito Internacional Penal. Revista CEJ, Brasília, Ano XIV, n. 51, p. 51-65, out./dez. 2010.

ESTADOS UNIDOS DA AMÉRICA. Bureau of Justice Statistics: Capital Punishment. Disponível em: <http://www.ojp.usdoj.gov/bjs/abstract/cp01.htm>. Acesso em: 21 abr. 2015.

FARIA, Glauco. Redução da maioridade: ilusão e oportunismo. Revista Fórum, 12 jun. 2013. Disponível em: <http://revistaforum.com.br/blog/2013/06/reducaoda-maioridade-ilusao-e-opor tunismo/>. Acesso em: 14 maio 2015.

GARCIA, Cláudia Viana. Sanções mais duras reduzem a taxa de 
SILVA, Andrey Gastaldi. HEIL, Danielle Mariel. Paralelismo da legislação do modelo Common Law sobre a pena de morte e a redução da maioridade penal no ordenamento jurídico brasileiro. Revista Eletrônica Direito e Política, Programa de Pós-Graduação Stricto Sensu em Ciência Jurídica da UNIVALI, Itajaí, v.11, n.3, $3^{\circ}$ quadrimestre de 2016. Disponível em: www.univali.br/direitoepolitica - ISSN 1980-7791

criminalidade? Postado em: 26 dez. 2011. Disponível em: <http://www.fatonotorio.com.br/artigos/ver/ 116/sancoes-mais-duras-reduzema-taxa-de-criminalidade>. Acesso em: 13 mar. 2015.

GODOY, Arnaldo Sampaio de Moraes. Direito penal nos Estados Unidos. Jus Navigandi, Teresina, ano 12, n. 1481, 22 jul. 2007. Disponível em: <http://jus.com.br/artigos/10179>. Acesso em: 10 mar. 2015.

GOMES, Nelci. Mais de $4 \%$ dos condenados à morte nos EUA são inocentes, indica estudo. JusBrasil, maio 2014. Disponível em: <http://nelcisgomes. jusbrasil.com.br/noticias/117938062/mais-de-4-dos-condenados-a-morte-noseua-sao-inocentes-indica-estudo?ref=home>. Acesso em: 27 maio 2015.

Todos os países que reduziram a maioridade penal não diminuíram a violência. Postado em: abr. 2014a. Disponível em: <http://nelcisg omes.jusbrasil. com.br/noticias/116624331/todos-os-paises-quereduziram-a-maioridade-penal-nao-diminuiram-a-violencia $>$. Acesso em: 20 maio 2015.

\section{G1. GLOBO. Americano é inocentado após passar 25 anos no corredor da} morte. Postado em: 12 mar. 2014. Disponível em: <http://g1.globo.com/mundo/noticia/2014/03/ameri cano-e-inocentado-apospassar-25-anos-no-corredor-da-morte.html>. Acesso em: 20 maio 2015.

LATZER, Barry. Death Penalty Cases. New York: Butterworth Heinemann, 2002.

LEITE, Arypson Silva. Impossibilidade constitucional de implantação da pena de morte no Brasil para os crimes comuns. Âmbito Jurídico, Rio Grande, $X V$, n. 102, jul. 2012. Disponível em: <http://www.ambito-juridico.com.br/site/index. $\mathrm{php} /$ ?n_link=revista_artigos_leitura\&artigo_id $=12002 \&$ revista_caderno $=9>$.

Acesso em: 02 maio 2015.

MAY, John Wilder. The Law of Crimes. Crime is a violation or neglect of legal duty, of so much public importance that the law, either common or statute, takes notice of and punishes it. Littleton: Fred B. Rothman, 1985.

MELLO, Mônica Barbosa Martins. A pena de morte à luz dos Direitos Humanos e do Direito Constitucional. 2008. Dissertação (Mestrado em Direito Constitucional) - Programa de Pós-Graduação em Direito, Fortaleza, Ceará, 2008. Disponível em: <http://www.ibamendes.com/2011/ 05/pena-demorte-no-brasil.html>. Acesso em: 14 abr. 2015.

MIRABETE, J. F. Manual de Direito Penal: parte geral. 27. ed. São Paulo: Atlas, 2012. V. 1.

MONTENEGRO, Manuel. CNJ divulga dados sobre nova população carcerária brasileira. Atualizado: 12 jun. 2014. Disponível em: <http://www.cnj.jus.br/noticias/cnj/ 28746-cnj-divulga-dados-sobre-novapopulacao-carceraria-brasileira >. Acesso em: 08 jun. 2015. 
SILVA, Andrey Gastaldi. HEIL, Danielle Mariel. Paralelismo da legislação do modelo Common Law sobre a pena de morte e a redução da maioridade penal no ordenamento jurídico brasileiro. Revista Eletrônica Direito e Política, Programa de Pós-Graduação Stricto Sensu em Ciência Jurídica da UNIVALI, Itajaí, v.11, n.3, $3^{\circ}$ quadrimestre de 2016. Disponível em: www.univali.br/direitoepolitica - ISSN 1980-7791

NICKNICH, Mônica. Ato infracional e poder judiciário: uma análise à luz do princípio da dignidade da pessoa humana. Blumenau: Nova Letra, 2010.

OLIVEIRA, Erival da Silva; GOLDZVEIG, Gustavo. Comentários à convenção americana de Direitos Humanos. São Paulo: ACJ, 2012.

OLIVEIRA, Gilberto Callado de. Garantismo e barbárie: a face oculta do garantismo penal. São Paulo: Conceito Editorial, 2011.

OLIVEIRA, Gleick Meira; LIMA, Rebecca Rocha. Do Direito Penal brasileiro: das penas e da pena de morte. Postado em: 2011. Disponível em:<http://www.ambitojuridico.com.br/site/index.phpn_link=revista_artigos_lei tura\%26artigo_id=9101"artigo_id=9101>. Acesso em: 15 mar. 2015.

PAZZIAN, Roberta Mucare. A descaracterização da prisão como forma de ressocializar o indivíduo. Postado em: 2012. Disponível em: <http://www. conamp.org.br/Lists/artigos/DispForm.aspx ID $=220 \&$ Source $=/>$. Acesso em: 12 abr. 2015.

RELATÓRIO MUNDIAL DOS ESTADOS UNIDOS DA AMÉRICA. Resumo do País. Human Rights Watch, p. 01-13, jan. 2014. Disponível em: <http://www.hrw.org/sites/default/files/related_material/US_pt\%202014\%2001 \%2004.pdf>. Acesso em: 02 maio 2015.

REVISTA ÂMBITO JURÍDICO. O debate da pena de morte: seus defensores e opositores. Disponível em: <http://www.ambitojuridico.com.br/pdfsGerados/artigos/ 3430.pdf>. Acesso em: 11 mar. 2015.

REVISTA DE DIREITOS E GARANTIAS FUNDAMENTAIS. Faculdade de Direito de Vitória - FDV, Vitória, jan./jun. 2013 (Direito - Periódicos).

ROSA, Alexandre Morais da. Redução da Idade Penal: "vale a pena ver de novo?" In: VALLE, Juliano Keller do; MARCELINO JÚNIOR, Júlio César. Reflexões da pós modernidade: Estado, Direito e Constituição. Florianópolis: Conceito Editorial, 2008.

ROSA, Paulo Tadeu Rodrigues; MACEROU, Eliane Ferreira. Pena de morte ou prisão perpétua: uma solução justa? Postado em: 26 fev. 2002. Disponível em: <http://www.ibccrim.org.br>. Acesso em: 23 abr. 2015.

SERRANO, Rodrigo Fagundes Luz. Pena de morte: aspectos jurídicos e religiosos. Postado em: $2008 . \quad$ Disponível em:<http://pt.scribd.com/doc/68141078/ARTIGO>. Acesso em: 16 maio 2015.

SILVA, Ana Beatriz Barbosa. Mentes perigosas: o psicopata mora ao lado. Rio de Janeiro: Objetiva, 2008.

SILVA, José Afonso da. Curso de Direito Constitucional Positivo. 24. ed. São Paulo: Malheiros, 2005. 
SILVA, Andrey Gastaldi. HEIL, Danielle Mariel. Paralelismo da legislação do modelo Common Law sobre a pena de morte e a redução da maioridade penal no ordenamento jurídico brasileiro. Revista Eletrônica Direito e Política, Programa de Pós-Graduação Stricto Sensu em Ciência Jurídica da UNIVALI, Itajaí, v.11, n.3, $3^{\circ}$ quadrimestre de 2016. Disponível em: www.univali.br/direitoepolitica - ISSN 1980-7791

SILVA, Marcelo Gomes. Menoridade penal: uma visão sistêmica. Rio de Janeiro. Lumen Juris, 2012.

SOARES, Anderson Real; NAPOLITANO JÚNIOR, Domingos. Uma análise sobre a pena de morte. Jornal do Advogado, OABSP, n. 305, p. 1-7, abr. 2006. Disponível em: <http://www.uniesp.edu.br/guaruja/site/revista/revista Edicao5Numero1/PDfs/artigo05_uma\%C3\%A1liseSobrePenaMorte.pdf>. Acesso em: 15 mar. 2015.

SOARES, Guido Fernandes Silva. Common Law: introdução ao Direito dos EUA. 2. ed. São Paulo: Revista dos Tribunais, 2000.

SOUSA, Carlo Arruda. O debate da pena de morte: seus defensores e opositores. Âmbito Jurídico, Rio Grande, $X, n$. 38, fev. 2007. Disponível em:<http://www.ambito-juridico.com.br/site/index.php?n_link=revista_artigos_ leitura\&artigo_id=3430>. Acesso em: 21 abr. 2015.

SOUZA, Jean Frederick Silva e. Pena de Morte: solução da violência ou violação do direito à vida? Revista de Direito e Liberdade, Escola da Magistratura do RN, Mossoró, v. 07, n. 03, p. 161-178, jul./dez. 2007.

TEXAS DEPARTAMENT OF CRIMINAL JUSTICE. Death Row Facts: history. Postado em: 2014. Disponível em: <https://www.tdcj.state.tx.us/death_row/dr_ facts.html>. Acesso em: 21 abr. 2015.

texAs Legislature Online. Texas Statutes. Penal Code. Disponível em: <http://www.capitol. state.tx.us>. Acesso em: 21 abr. 2014.

WALLACE, Harvey; ROBERSON, Cliff. Principles of Criminal Law. White Plains: Longman, 1996.

XAVIER, Ana Paula Krentz. Aplicabilidade e eficácia da pena de morte como instrumento de defesa social: estudo de caso nos Estados Unidos da América. 2004. 99 f. Monografia (Bacharel em Direito) - Universidade do Vale do Itajaí, São José, 2004. Disponível em: <http://siaibib01.univali.br/pdf/Ana\% 20Xavier.pdf>. Acesso em: 14 mar. 2015.

ZAFFARONI, Eugenio Raúl; PIERANGELI, José Henrique. Manual de Direito Penal brasileiro: parte geral. 4. ed. rev. São Paulo: Revista dos Tribunais, 2002.

Submetido em: julho/2016

Aprovado em: setembro/2016 